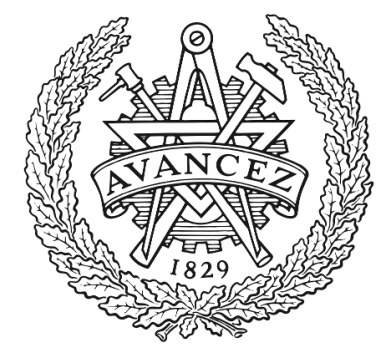

CHALMERS

UNIVERSITY OF TECHNOLOGY

\title{
Toward Reversible and Moisture-Tolerant Aprotic Lithium-Air Batteries
}

Downloaded from: https://research.chalmers.se, 2023-04-26 12:03 UTC

Citation for the original published paper (version of record):

Temprano, I., Liu, T., Petrucco, E. et al (2020). Toward Reversible and Moisture-Tolerant Aprotic Lithium-Air Batteries. Joule, 4(11): 2501-2520. http://dx.doi.org/10.1016/j.joule.2020.09.021

N.B. When citing this work, cite the original published paper. 


\section{Article}

\section{Toward Reversible and Moisture-Tolerant Aprotic Lithium-Air Batteries}

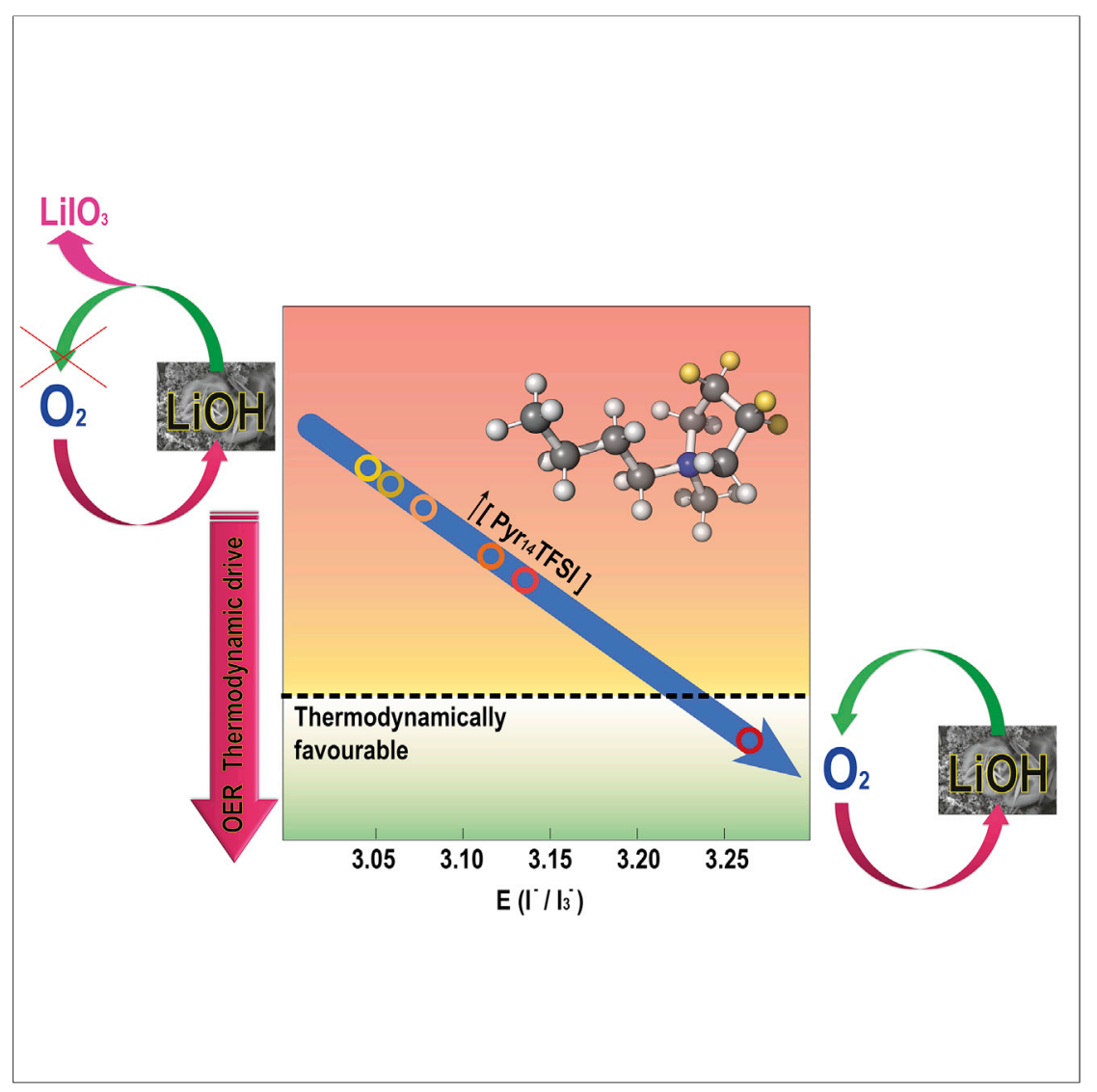

Li-air batteries have attracted significant attention due to their very high energy density, comparable to that of fossil fuels. For their development, a stable discharge product that can be reversibly decomposed during charge needs to be developed. $\mathrm{LiOH}$ is a promising candidate, but questions concerning the reversibility of the charge process have been raised. Here, we report for the first time $\mathrm{Li}-\mathrm{O}_{2}$ cells that can reversibly cycle via $\mathrm{LiOH}$ by using water and an ionic liquid as additives in the electrolyte.
Israel Temprano, Tao Liu, Enrico Petrucco, James H.J. Ellison, Gunwoo Kim, Erlendur Jónsson, Clare P. Grey

cpg27@cam.ac.uk

\section{HIGHLIGHTS}

lodide-mediated $\mathrm{Li}_{-} \mathrm{O}_{2}$ cells can reversibly cycle via $\mathrm{LiOH}$ with low overpotential

Electrolyte additives can increase the redox potential of the $\mathrm{I}^{-} / \mathrm{I}_{3}{ }^{-}$ couple

At sufficiently high $\mathrm{I}^{-} / \mathrm{I}_{3}{ }^{-}$redox potentials, OER from $\mathrm{LiOH}$ becomes favorable 


\title{
Article
}

\section{Toward Reversible and Moisture-Tolerant Aprotic Lithium-Air Batteries}

\author{
Israel Temprano, ${ }^{1}$ Tao Liu, ${ }^{1,4}$ Enrico Petrucco, ${ }^{2}$ James H.J. Ellison, ${ }^{1}$ Gunwoo Kim, ${ }^{1}$ Erlendur Jónsson, ${ }^{1,3}$ \\ and Clare P. Grey ${ }^{1,5, *}$
}

\section{SUMMARY}

The development of moisture-tolerant, $\mathrm{LiOH}$-based non-aqueous Li$\mathrm{O}_{2}$ batteries is a promising route to bypass the inherent limitations caused by the instability of their typical discharge products, $\mathrm{LiO}_{2}$ and $\mathrm{Li}_{2} \mathrm{O}_{2}$. The use of the $\mathrm{I}^{-} / \mathrm{I}_{3}{ }^{-}$redox couple to mediate the $\mathrm{LiOH}$ based oxygen reduction and oxidation reactions has proven challenging due to the multiple reaction paths induced by the oxidation of $\mathrm{I}^{-}$on cell charging. In this work, we introduce an ionic liquid to a glyme-based electrolyte containing Lil and water and demonstrate a reversible $\mathrm{LiOH}-$ based $\mathrm{Li}^{-} \mathrm{O}_{2}$ battery cycling that operates via a $4 \mathrm{e}^{-} / \mathrm{O}_{2}$ process with a low charging overpotential (below $3.5 \mathrm{~V}$ versus $\mathrm{Li} / \mathrm{Li}^{+}$). The addition of the ionic liquid increases the oxidizing power of $\mathrm{I}_{3}{ }^{-}$, shifting the charging mechanism from $1 \mathrm{O}^{-} / \mathrm{IO}_{3}{ }^{-}$formation to $\mathrm{O}_{2}$ evolution.

\section{INTRODUCTION}

In light of recent commitments from several European countries to ban the sale of internal combustion engine vehicles in the coming decades, ${ }^{1,2}$ the race to develop electrical storage strategies beyond the capabilities of lithium-ion batteries is intensifying considerably. Among the many different options, Li-air batteries have attracted significant attention due to their comparable energy density to fossil fuels. ${ }^{3}$

Non-aqueous Li-air batteries (LABs) are generally composed of a lithium-metal anode, an organic-based lithium-ion conducting liquid electrolyte, and a porous, typically carbon-based, cathode. During discharge, $\mathrm{O}_{2}$ is reduced at the cathode (the oxygen reduction reaction, ORR), which then combines with lithium ions in solution, forming insoluble discharge products that fill up the porous structure of the carbon electrode. The discharge product is oxidized during charge, with $\mathrm{O}_{2}$ being released back to the atmosphere (the oxygen evolution reaction, OER). ${ }^{4}$

Despite its potential, several fundamental challenges remain to be overcome to allow the successful development of a practical non-aqueous LAB. ${ }^{4-8}$ Among these challenges, the instability of the typical discharge products $\left(\mathrm{LiO}_{2}\right.$ and $\left.\mathrm{Li}_{2} \mathrm{O}_{2}\right)$ in the presence of moisture and $\mathrm{CO}_{2}$ represents a fundamental stumbling block. ${ }^{9,10}$ Recently, it has been shown that lithium hydroxide $(\mathrm{LiOH})$ can be formed as a discharge product in moisture-tolerant LABs with a high capacity and low charge overpotential using either Lil as a redox mediator or Ru as a catalyst in a wet organic electrolyte. ${ }^{11-13}$ However, it is widely believed that $\mathrm{LiOH}$ is not reversible due to (1) the half-cell potential of the $\mathrm{LiOH}$ OER under standard state (aqueous) conditions being higher than that of the $\mathrm{Li}_{2} \mathrm{O}_{2} \mathrm{OER}$, given the higher thermodynamic stability of the former; (2) the detection on charge of oxidation products such as

\section{Context \& Scale}

Li-air batteries have attracted significant attention as a strategy to develop affordable and sustainable electrical storage with higher energy density than current lithium-ion batteries, having theoretical energy densities that rival those of fossil fuels and, in their simplest form, avoiding the use of resource-limited transition metal oxides. The formation of $\mathrm{LiOH}$ as discharge product is a promising route to bypass some of the most acute challenges this very young technology faces. However, one critical challenge is to charge the battery reversibly, evolving oxygen gas at low overpotentials. While previous studies have indicated that the $\mathrm{I}^{-} /$ $\mathrm{I}_{3}{ }^{-}$redox couple may not have sufficient thermodynamic drive for the oxygen evolution reaction, here we demonstrate that additives in the electrolyte (ionic liquid and water) can increase the $\mathrm{I}^{-} / \mathrm{I}_{3}^{-}$equilibrium redox potential sufficiently to enable a reversible charge process at low overpotentials. 
$\mathrm{IO}_{3}{ }^{-12,14,15}$ and $\mathrm{DMSO}_{2}{ }^{13}$ which originate from the redox mediator and the solvents, respectively; and (3) little or no oxygen evolution being observed in gas analysis experiments. ${ }^{14}$ These observations have given rise to doubts as to whether the iodide/triiodide $\left(\mathrm{I}^{-} / \mathrm{I}_{3}{ }^{-}\right)$redox system is capable of sustaining reversible ORR/OER chemistry via $\mathrm{LiOH}$ formation and decomposition. ${ }^{14-17}$

The electrochemical behavior of the iodide/triiodide redox system has been extensively reported in the literature, and it is by now well established that the $\left(\mathrm{I}^{-} / \mathrm{I}_{3}{ }^{-}\right)$redox potential is solvent dependent ${ }^{12,18-20}$ : the oxidizing power of $\mathrm{I}_{3}{ }^{-}$can be readily tailored by means of adjusting the physicochemical parameters of the electrolyte (dielectric constant, ionic strength, Gutmann acceptor/donor numbers, etc.). Ionic liquids (ILs) have been shown to alter the solvation/coordination environments of this redox system, again substantially affecting the $\left(\mathrm{I}^{-} / \mathrm{I}_{3}{ }^{-}\right)$redox potential, ${ }^{18}$ while still allowing high ionic conductivity and reducing solvent volatility. ${ }^{21-28}$ However, the high viscosity of ILs, which reduces the $\mathrm{O}_{2}$ diffusion coefficients, and the low $\mathrm{O}_{2}$ solubility are disadvantageous for $L A B$ performance. ${ }^{29}$ The presence of water has been shown to enhance the solution-transfer of discharge products and redox mediators, ${ }^{12,30-33}$ reducing the charge overpotential and therefore the level of parasitic reactions, as well as fundamentally affecting the activity of the $\left(\mathrm{I}^{-} / \mathrm{I}_{3}^{-}\right)$redox system during discharge. ${ }^{11,14,34}$ Thus, the combination of Lil as redox mediator with water and an ionic liquid is a potentially good strategy for efficiently tailoring the electrolyte properties in $\mathrm{Li}_{-} \mathrm{O}_{2}$ batteries.

In this work, we report a step forward toward the realization of a viable moisturetolerant $\mathrm{LAB}$, by reversibly cycling $\mathrm{LiOH}$ with low charging overpotentials in cells with Lil as a redox mediator and $\mathrm{H}_{2} \mathrm{O}$ and 1-butyl-1-methyl-pyrrolidinum-bis(trifluoromethanesulfonyl)imide ( Pyr $_{14}$ TFSI) as additives in a low-volatility electrolyte. $\mathrm{Pyr}_{14}$ TFSI is one of the most widely studied ILs in relation to $\mathrm{Li}_{-} \mathrm{O}_{2}$ batteries, showing high stability toward superoxide species and a relatively high $\mathrm{Li}^{+}$diffusion coefficient. ${ }^{24,28,29,31,35-37}$ We find that the inclusion of $\mathrm{Pyr}_{14}$ TFSI is crucial for the reversibility of the electrochemical formation/decomposition of $\mathrm{LiOH}$ as demonstrated by the observation of a $4 \mathrm{e}^{-} / \mathrm{O}_{2}$ OER using operando online electrochemical mass spectrometry (OEMS). OER from $\mathrm{LiOH}$ decomposition is further confirmed by OEMS experiments with (electrochemically) preloaded electrodes, as well as isotopic labeling. The suppression of the side reactions to form oxygenated iodine species $\left(\mathrm{IO}^{-}, \mathrm{IO}_{3}^{-}\right)$, which trap the oxygen during charge, is also observed, and the mechanistic considerations of the oxygen evolution versus iodate formation are discussed in the context of the thermodynamic driving forces for both reactions. The effects of the IL and water with respect to the activity of iodine are also investigated through molecular dynamic (MD) simulations.

\section{RESULTS AND DISCUSSION}

\section{A $4 \mathrm{e}^{-} / \mathrm{O}_{2}$ Oxygen Evolution Reaction}

$\mathrm{Li}-\mathrm{O}_{2}$ cells were constructed with a lithium-metal anode, an anolyte consisting of 300 mM LiTFSI in tetraethylene glycol dimethyl ether (G4), a lithium-ion conducting glass ceramic (LICGC-Ohara AG010) separating the two electrolytes, a catholyte containing $700 \mathrm{mM} \mathrm{LiTFSI}, 50 \mathrm{mM}$ Lil, $900 \mathrm{mM} \mathrm{Pyr}{ }_{14}$ TFSI, and 5,000 ppm $\mathrm{H}_{2} \mathrm{O}$ in G4, and a mesoporous carbon black cathode (Ensaco-P150). The LICGC serves to prevent redox shuttling $\left(\mathrm{I}^{-} / \mathrm{I}_{3}{ }^{-}\right)$and reaction of catholyte additives with the Li anode, since redox mediator shuttling is a possible source of "artificial" capacity, the oxidized species such as $\mathrm{I}_{3}{ }^{-}$being reduced at the anode and then migrating back to the cathode to be reoxidized. ${ }^{14}$ These cells were evaluated with operando OEMS by capacity-limiting galvanostatic cycling, in order to keep the levels of water within limits
1 Department of Chemistry, University of Cambridge, Cambridge CB2 1EW, UK

2Johnson Matthey Technology Centre, Blounts Court, Sonning Common, Reading RG4 9NH, UK

${ }^{3}$ Department of Physics, Chalmers University of Technology, Gothenburg 41296, Sweden

${ }^{4}$ Present address: Shanghai Key Laboratory of Chemical Assessment and Sustainability, Department of Chemistry, Tongji University, Shanghai 200092, China

5 Lead Contact

*Correspondence: cpg27@cam.ac.uk

https://doi.org/10.1016/j.joule.2020.09.021 

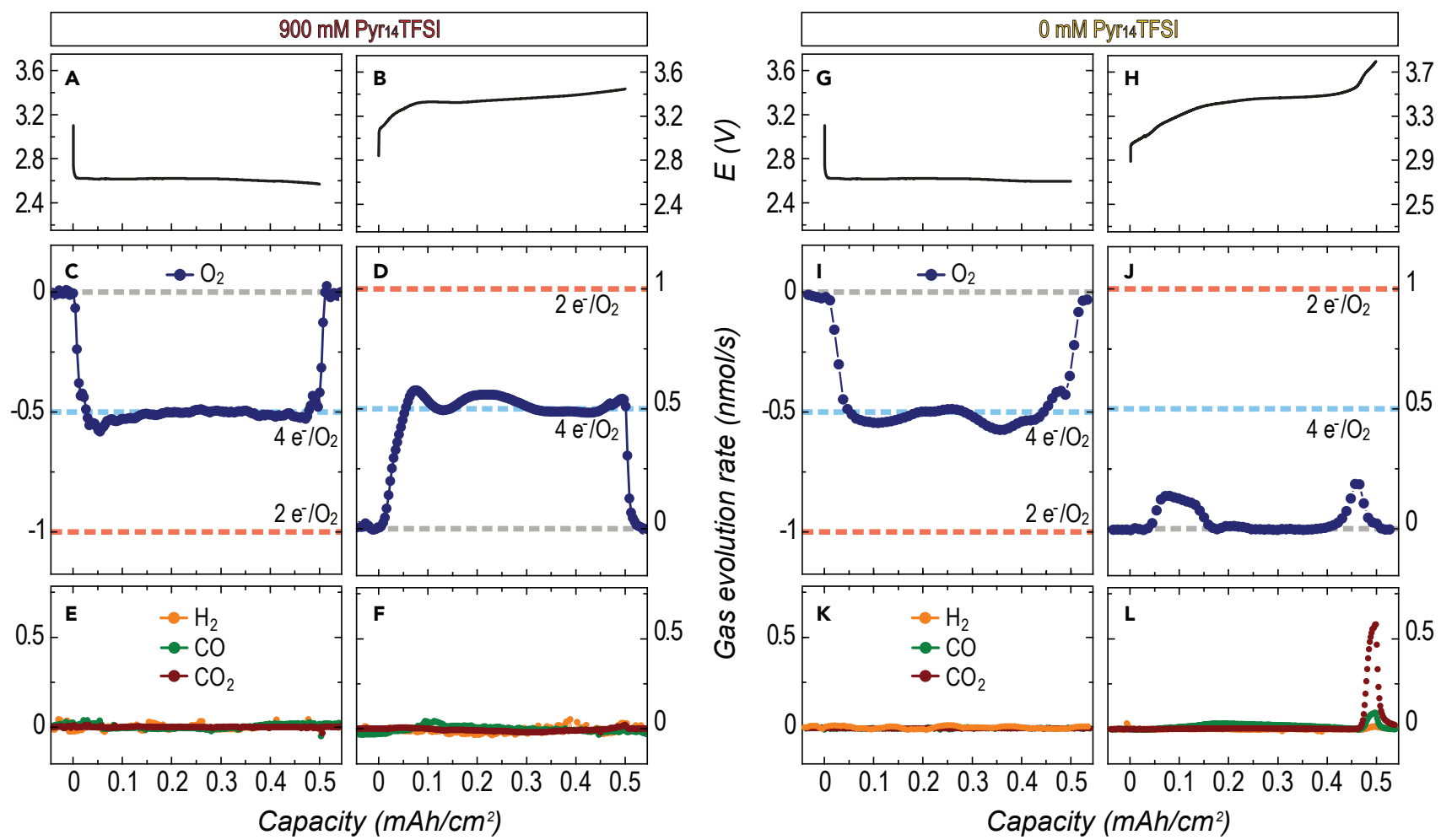

Figure 1. $4 \mathrm{e}^{-} / \mathrm{O}_{2}$ Formation and Removal of LiOH in Water and IL-Containing Cells

$(A, B, G, H)$ Galvanostatic profiles and $(C, D, I, J)$ online mass spectrometry analysis of $\mathrm{O}_{2}$, and $(E, F, K, L) ~ H_{2}, C O$, and $C O_{2}(m / z=32,2,28,44$, respectively) from batteries with electrolytes comprising of $700 \mathrm{mM} \mathrm{LiTFSI,} 50 \mathrm{mM} \mathrm{Lil,} \mathrm{and} \mathrm{5,000} \mathrm{ppm} \mathrm{H}_{2} \mathrm{O}$ in G4 with 900 mM Pyr ${ }_{14}$ TFSI (left) and without $\mathrm{Pyr}_{14}$ TFSI (right) cycled at a current of $50 \mu \mathrm{A} / \mathrm{cm}^{2}$.

known for promoting $\mathrm{LiOH}$ formation during the ORR (between 1,500 and 5,000 ppm). ${ }^{11}$ Figure 1 (system description in Figure S1A) shows the electrochemical profile (Figures $1 \mathrm{~A}$ and $1 \mathrm{~B}$ ) and gas evolution rate of $\mathrm{O}_{2}(\mathrm{~m} / \mathrm{z}=32$; Figures $1 \mathrm{C}$ and $1 \mathrm{D})$, $\mathrm{H}_{2}, \mathrm{CO}$, and $\mathrm{CO}_{2}(\mathrm{~m} / \mathrm{z}=2,28,44$; Figures $1 \mathrm{E}$ and $1 \mathrm{~F})$ for the discharge and charge of this cell (Figures $1 \mathrm{G}-1 \mathrm{M}$ show similar results for a cell without $\mathrm{Pyr}_{14} \mathrm{TFSI}$ for comparison). The electrochemical discharge profile (Figure 1A) shows a sustained single discharge plateau at $2.6 \mathrm{~V}$ (versus $\mathrm{Li} / \mathrm{Li}^{+}$). The discharge produces a constant consumption rate of $\mathrm{O}_{2}$ of $\sim 0.51 \mathrm{nmol} / \mathrm{s}$ (Figure $1 \mathrm{C}$ ), corresponding to a $4 \mathrm{e}^{-} / \mathrm{O}_{2}$ stoichiometry, with no significant evolution of gases indicative of parasitic reactions (Figure $1 \mathrm{E}$ ). The total measured $\mathrm{O}_{2}$ consumption is $18.5 \mathrm{mmol}$, which corresponds to a 99.1\% faradic efficiency.

The charge profile shows an initial rapid increase in potential from 3.1 to $3.3 \mathrm{~V}$ followed by a relatively flat process at approximately 3.4 V (Figure 1B). Notably, oxygen evolution is clearly observed to occur from the beginning of charge, stabilizing at around a rate corresponding to a $4 \mathrm{e}^{-} / \mathrm{O}_{2}$ stoichiometry (Figure 1D). A total of $18.4 \mathrm{mmols}$ of $\mathrm{O}_{2}$ is evolved during charge, corresponding to $99.5 \%$ of the amount consumed in the discharge (i.e., a $99.5 \%$ faradic efficiency), with no significant signs of parasitic reactions as signaled by a lack of evolution of $\mathrm{H}_{2}, \mathrm{CO}$, or $\mathrm{CO}_{2}$ (Figure 1F). The OER can be observed for several cycles (Figure S5) with a relatively high faradic efficiency $(>80 \%$ for 7 cycles).

By comparison, in the absence of $\mathrm{Pyr}_{14} \mathrm{TFSI}$, only very small amounts of $\mathrm{O}_{2}$ (1.5 mmols corresponding to $\sim 8.4 \%$ faradic efficiency) (Figure $1 \mathrm{~K}$ ) are detected 


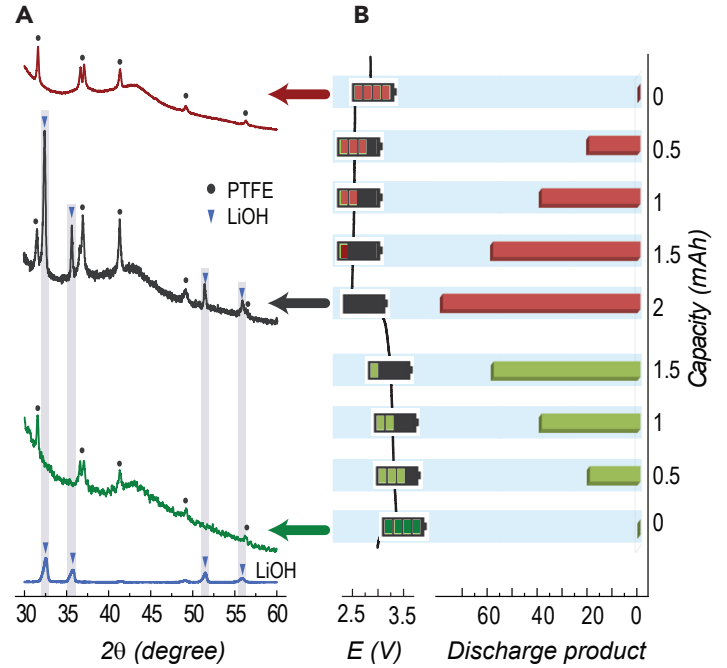

( $\mu \mathrm{mol})$

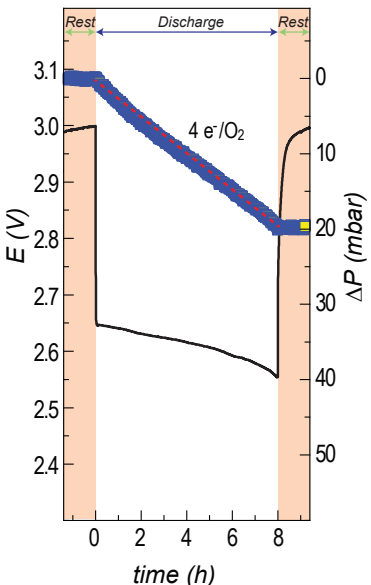

D

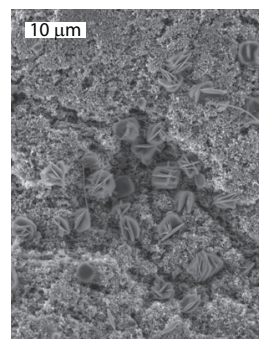

E

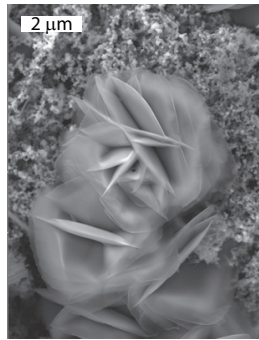

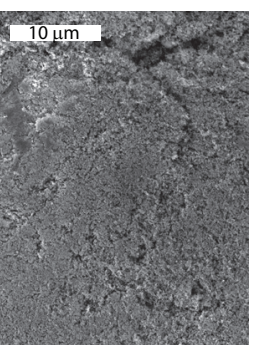

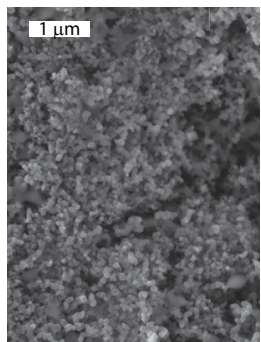

Figure 2. Operando and Ex Situ Characterization of the LiOH Formation during ORR (A) X-ray diffractograms at different stages of capacity-limited cycling (pristine, red; discharged, gray; fully charged, green) as represented in the electrochemical profile.

(B) Quantification of $\mathrm{LiOH}$ present in the electrode by acid/base titration at different stages of capacity-limited cycling.

(C) Operando pressure-monitoring experiment during discharge.

( $D$ and E) SEM characterization (at two different magnifications) of electrodes at the end of discharge (D) and end of charge (E) (scale bars shown in white).

Relevant reflections due to $\mathrm{LiOH}$ and PTFE binder are indicated by gray triangles and blue dots, respectively, in (A). All cells were cycled at $50 \mu \mathrm{A} / \mathrm{cm}^{2}$.

during charge to $3.5 \mathrm{~V}$. A steep increase in potential above $3.6 \mathrm{~V}$ at the end of charge is also observed, which is accompanied by a significant evolution of $\mathrm{CO}_{2}$ (and $\mathrm{O}_{2}$ and $\mathrm{CO}$ to lesser extent), suggesting electrode/electrolyte degradation (Figure 1M).

\section{Analysis of the ORR Products}

Analysis of the cathode after discharge with X-ray diffraction (XRD) (Figure 2A, gray trace) is dominated by patterns corresponding to crystalline $\mathrm{LiOH}$, as revealed by quantitative analysis of the diffraction pattern (Figure S2). All reflections associated with $\mathrm{LiOH}$ are absent in the diffractogram of the fully charged electrodes, confirming the removal of the crystalline discharge product (Figure 2A, green trace). Quantification of the amount of $\mathrm{LiOH}$ present in the electrode was performed by acid titration at various stages of the discharge $(1 / 4,1 / 2,3 / 4$, and full discharge) and the charge $(1 / 4$, $1 / 2,3 / 4$, and full charge) processes. Figure $2 \mathrm{~B}$ shows an increasing amount of $\mathrm{LiOH}$ detected in the electrode as the ORR progresses (red bars), which matches the expected value for a $1 \mathrm{e}^{-} / \mathrm{LiOH}$ mechanism $\left(4 \mathrm{e}^{-} / \mathrm{O}_{2}\right)$ at all stages of discharge. The presence of $\mathrm{Li}_{2} \mathrm{O}_{2}$ as an alternative discharge product was also tested by iodometry 
titration (Figure S3); no peroxide was detected, in agreement with the XRD analysis. A similar trend can be observed during different stages of the OER (Figure $2 \mathrm{~B}$, green bars), indicating that $\mathrm{LiOH}$ is being removed according to the same $1 \mathrm{e}^{-} / \mathrm{LiOH}$ stoichiometry. Operando pressure monitoring during discharge (Figure 2C) confirms a $4 \mathrm{e}^{-} / \mathrm{O}_{2}$ stoichiometry during ORR for cells with $900 \mathrm{mM} \mathrm{Pyr}{ }_{14} \mathrm{TFSI}$ and 5,000 ppm of water, as expected for the formation of $\mathrm{LiOH}$. These results suggest that galvanostatic cycling of this cell occurs through the formation and removal of $\mathrm{LiOH}$, and not through $\mathrm{Li}_{2} \mathrm{O}_{2}$ chemistry under the experimental conditions shown in Figure 1 (Figure S6).

Scanning electron microscopy (SEM) images of electrodes during the first discharge are shown in Figure 2D. The electrodes extracted from capacity-limited cells ( 2 mAh) discharged cells contain typical "flower-like" $\mathrm{LiOH}$ crystals of up to $7 \mu \mathrm{m}$ in size, similar to those previously reported in cells containing Lil and water. ${ }^{12}$ The absence of these crystalline structures in the SEM images of fully recharged electrodes (Figure $2 \mathrm{E}$ ) confirms the removal of the discharge product during charge without the precipitation of large quantities of by-products from parasitic reactions. The consumption/regeneration of water, consistent with the reversible formation/decomposition of $\mathrm{LiOH}$ through the mechanism presented in Reaction 1, was also observed (Figure S7).

In order to evaluate the mechanistic implications of the observed stoichiometry during the OER in Figure 1, further OEMS experiments were performed with an electrochemically preloaded electrode with $\mathrm{Li}_{2} \mathrm{O}_{2}$ (Figure 3, left); the electrode was produced by discharging a cell using $300 \mathrm{mM}$ LiTFSI in G4 as the electrolyte (i.e., with no Lil or additives). The cell was subsequently disassembled in the glove box, and the electrode was washed 3 times with ethylene glycol dimethyl ether (G1) and dried under vacuum for $30 \mathrm{~min}$. This electrode was then loaded in a two-compartment cell with the same catholyte used for the cells shown in Figure 1 (i.e., $700 \mathrm{mM}$ LiTFSI, $50 \mathrm{mM}$ Lil, $900 \mathrm{mM} \mathrm{Pyr}{ }_{14}$ TFSI, and 5,000 ppm $\mathrm{H}_{2} \mathrm{O}$ in G4). In this case, the OER showed an approximately $2 \mathrm{e}^{-} / \mathrm{O}_{2}$ stoichiometry (Figure $3 \mathrm{C}$ ), consistent with the oxidation of $\mathrm{Li}_{2} \mathrm{O}_{2}$. After initially reaching an evolution rate corresponding to $2 \mathrm{e}^{-} / \mathrm{O}_{2}$, a noticeable dip in the oxygen evolution is seen (Figure $3 \mathrm{C}$ ). This effect has been previously attributed to a transition from the delithiation of $\mathrm{Li}$-deficient $\left(\mathrm{Li}_{2-x} \mathrm{O}_{2}\right)$ species to stoichiometric $\mathrm{Li}_{2} \mathrm{O}_{2}$ on $\mathrm{Li}_{2} \mathrm{O}_{2}$ particles. ${ }^{38-40}$ Preloading was similarly performed using the IL-free conditions previously shown to produce $\mathrm{LiOH}$ electrochemically: ${ }^{11}$ an electrolyte comprising $700 \mathrm{mM} \mathrm{LiTFSI}$, $50 \mathrm{mM} \mathrm{Lil}$, and 5,000 ppm $\mathrm{H}_{2} \mathrm{O}$ in $\mathrm{G} 4$ was discharged. Switching to the IL-containing electrolyte resulted in $4 \mathrm{e}^{-} / \mathrm{O}_{2}$, OER on charge (Figure S12).

Since earlier ${ }^{17} \mathrm{O}$-ssNMR measurements have reported that both $\mathrm{O}_{2}$ and $\mathrm{H}_{2} \mathrm{O}$ contribute to the oxygen atoms in the $\mathrm{LiOH}$ formed via a Lil-catalyzed electrochemical reaction in G1, ${ }^{11}$ a further OEMS experiment was performed using ${ }^{17} \mathrm{O}$-enriched $\mathrm{H}_{2} \mathrm{O}$ (Figure 3, right) and $\mathrm{Pyr}_{14}$ TFSI. A m/z = 32 mass spectrometer signal (Figure 3D, blue) dominates the response on charge, which is due to ${ }^{16} \mathrm{O}-{ }^{16} \mathrm{O}$. A signal is seen at $\mathrm{m} / \mathrm{z}=33$ (Figure 3D, magenta), which corresponds to ${ }^{17} \mathrm{O}-{ }^{16} \mathrm{O}$. The signal at $\mathrm{m} / \mathrm{z}=$ 34 (Figure 3D, orange) corresponds to either ${ }^{17} \mathrm{O}-{ }^{17} \mathrm{O}$ or ${ }^{18} \mathrm{O}-{ }^{16} \mathrm{O}$. Since the signal intensity of the $\mathrm{m} / \mathrm{z}=33$ and 34 signals are similar in magnitude, this indicates that the $\mathrm{m} / \mathrm{z}=33$ signal is not due to the ${ }^{17} \mathrm{O}$ in $\mathrm{O}_{2}$ gas, since the natural abundance of ${ }^{17} \mathrm{O}$ and ${ }^{18} \mathrm{O}$ are $0.04 \%$ and $0.2 \%$, respectively. The low enrichment of the $\mathrm{H}_{2}{ }^{17} \mathrm{O}$ resulted in a relatively low $\mathrm{Li}^{17} \mathrm{OH}$ concentration, as observed by ${ }^{17} \mathrm{O}$ ssNMR (Figure $\mathrm{S} 13$ ). This explains the relatively low intensity of the $\mathrm{m} / \mathrm{z}=33$ signal (from ${ }^{16} \mathrm{O}-{ }^{17} \mathrm{O}$ ) compared with the $\mathrm{m} / \mathrm{z}=32$ signal (from ${ }^{16} \mathrm{O}-{ }^{16} \mathrm{O}$ ). 


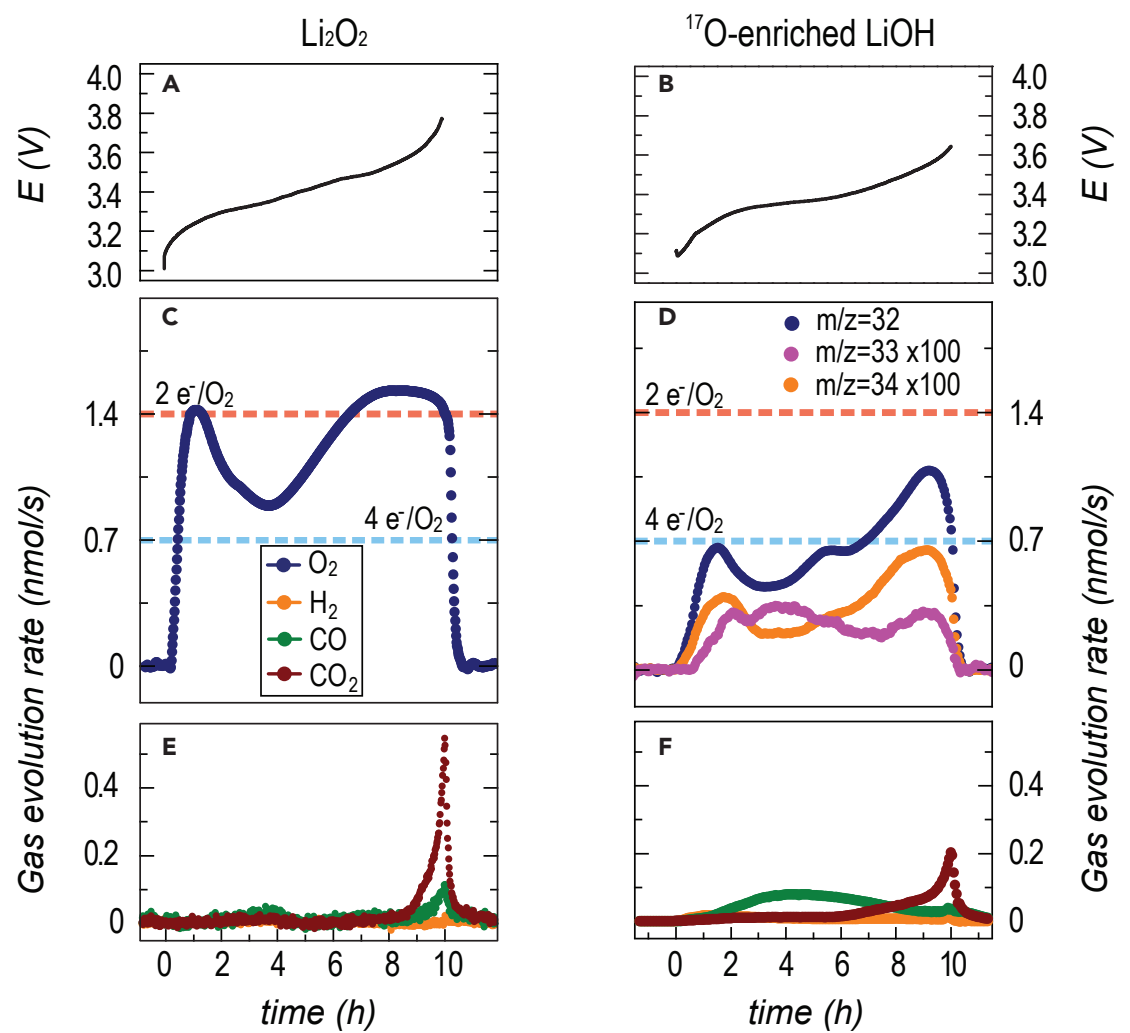

Figure 3. Operando Gas Analysis of Preloaded Electrodes and Isotopic Exchange during OER (A and B) Galvanostatic profiles (top) and ( $C$ and $D$ ) online mass spectrometry analysis of $\mathrm{O}_{2}(\mathrm{~m} / \mathrm{z}=$ 32) and $(E$ and $F) \mathrm{H}_{2}, \mathrm{CO}$, and $\mathrm{CO}_{2}(\mathrm{~m} / \mathrm{z}=2,28,44)$ evolution during charge of electrochemically preloaded electrodes with $\mathrm{Li}_{2} \mathrm{O}_{2}$ (left) and of a $\mathrm{Li}_{-} \mathrm{O}_{2}$ cell discharged using ${ }^{17} \mathrm{O}$-enriched $\mathrm{H}_{2} \mathrm{O}$ in the electrolyte containing $\mathrm{G} 4$ and $\mathrm{Pyr}_{14} \mathrm{TFSI}$ at $70 \mu \mathrm{A} / \mathrm{cm}^{2}$.

\section{Pathways to LiOH Removal}

The mechanisms for $\mathrm{LiOH}$ formation in the ORR reaction have been discussed extensively elsewhere, ${ }^{11,15,34}$ and thus we focus here on the OER reaction during charge (verification of the ORR mechanism is shown in Figure S14). Two questions arise from the OEMS data (Figure 1). First, what is the role played by $\mathrm{Pyr}_{14} \mathrm{TFSI}$ in the promotion of oxygen evolution? Second, what is the mechanism for $\mathrm{LiOH}$ decomposition/ removal in the absence of the ionic liquid when there is no $\mathrm{O}_{2}$ evolution?

The OER, during the charge of a $\mathrm{LiOH}$-based $\mathrm{Li}-\mathrm{O}_{2}$ battery, can be described overall by:

$$
4 \mathrm{Li}^{+}{ }_{(\text {sol })}+4 \mathrm{OH}^{-} \text {(sol) } \rightleftarrows 2 \mathrm{H}_{2} \mathrm{O}_{(\text {sol })}+\mathrm{O}_{2(\text { sol })}+4 \mathrm{Li}_{(\mathrm{s})} \text {. }
$$

(Reaction 1)

However, this reaction operates via a two-stage catalytic mechanism in which $\mathrm{I}^{-}$is first oxidized to $\mathrm{I}_{3}{ }^{-}$(the $\mathrm{I}^{-} / \mathrm{I}_{3}{ }^{-}$couple, here referenced to the $\mathrm{Li}$ anode [the $\mathrm{Li} / \mathrm{Li}^{+}$ couple]),

$$
2 \mathrm{Li}^{+}{ }_{(\mathrm{sol})}+3 \mathrm{I}^{-}{ }_{(\text {sol })} \rightleftarrows \mathrm{I}_{3}^{-}{ }_{(\text {sol })}+2 \mathrm{Li}_{(\mathrm{s})}
$$

(Reaction 2)

and, subsequently, $\mathrm{LiOH}$ is oxidized to $\mathrm{O}_{2}$ by $\mathrm{l}_{3}{ }^{-}$with the regeneration of $\mathrm{I}^{-}\left(\mathrm{OH}^{-} \rightarrow\right.$ $\mathrm{O}_{2}$ chemical reaction):

$$
4 \mathrm{OH}^{-}{ }_{\text {(sol) }}+2 \mathrm{I}_{3}{ }^{-} \text {(sol) } \rightleftarrows 6 \mathrm{I}^{-}{ }_{\text {(sol) }}+2 \mathrm{H}_{2} \mathrm{O}_{\text {(sol) }}+\mathrm{O}_{2 \text { (sol) }} \text {. }
$$


The $\left(\mathrm{I}^{-} / \mathrm{I}_{3}{ }^{-}\right)$redox potential at standard (aqueous) conditions $\left(\mathrm{E}^{\circ}\right.$ versus $\left.\mathrm{Li} / \mathrm{Li}^{+}\right)$corresponds to $3.5761 \mathrm{~V},{ }^{18,41}$ which is sufficiently large to drive oxygen evolution. However, the reversibility of iodide-mediated aprotic $\mathrm{Li}_{-} \mathrm{O}_{2}$ batteries, cycling through $\mathrm{LiOH}$, has been a much-discussed subject due to the difficulty of performing the OER process at low overpotentials (below $3.5 \mathrm{~V}$ ). ${ }^{14-17,19}$ Alternative reaction pathways have therefore been proposed in the literature to explain the $\mathrm{LiOH}$ removal upon charging in Lil- and organic-electrolyte-containing cells with added water. The detection of $\mathrm{IO}_{3}{ }^{-}$in the electrolyte of charged cells, alongside the lack of $\mathrm{O}_{2}$ evolution in OEMS experiments, has suggested that $\mathrm{IO}_{3}{ }^{-}$is the dominant product rather than $\mathrm{O}_{2}$ at $3.5 \mathrm{~V}$ or below, in ether-based electrolytes. The $\mathrm{IO}_{3}{ }^{-}$formation has been proposed to form either through the oxidation of $\mathrm{I}^{-}$to $\mathrm{I}_{2}$

$$
2 \mathrm{I}^{-} \rightleftarrows \mathrm{I}_{2}+2 \mathrm{e}^{-}
$$

(Reaction 4)

and its subsequent chemical reaction with $\mathrm{LiOH}^{14,15}$ :

$$
3 \mathrm{I}_{2}+6 \mathrm{OH}^{-} \rightleftarrows 1 \mathrm{O}_{3}^{-}+5 \mathrm{I}^{-}+3 \mathrm{H}_{2} \mathrm{O}
$$

(Reaction 5)

or via oxidation by $\mathrm{I}_{3}^{-}$to form $\mathrm{IO}^{-}$and the subsequent disproportionation of $\mathrm{IO}^{-}$ into $\mathrm{IO}_{3}^{-}$and $\mathrm{I}^{-18,42}$ :

$$
6 \mathrm{OH}^{-}+3 \mathrm{I}_{3}^{-} \rightleftarrows 8 \mathrm{I}^{-}+3 \mathrm{H}_{2} \mathrm{O}+\mathrm{IO}_{3}^{-} \text {. }
$$

(Reaction 6)

In this study, cells containing Pyr ${ }_{14}$ TFSI show clear evidence for a $4 \mathrm{e}^{-} / \mathrm{O}_{2}$ OER (Reaction 1) commencing at $\sim 3.2 \mathrm{~V}$ (Figures $1 \mathrm{~A}-1 \mathrm{~F}$ ). This oxygen evolution is absent in cells without the IL (Figures 1G-1M), even when charging at comparable potentials (below $3.5 \vee$ for $\sim 75 \%$ of charge).

Characterization of the electrolyte after charge was performed in order to establish the products formed following $\mathrm{LiOH}$ removal in cells with and without IL and thus investigate the difference in mechanism during the OER. UV spectra of aliquots of the electrolyte of charged cells with and without Pyr $_{14}$ TFSI (Figure 4A) show the presence of features at 295 and $354 \mathrm{~nm}$, corresponding to the presence of $\mathrm{I}_{3}{ }^{-}$; no feature corresponding to $\mathrm{I}_{2}$ (at $520 \mathrm{~nm}$ ) is seen in either case (insert in Figure 4A). The electrolyte of cells without Pyr ${ }_{14}$ TFSI (Figure 4A, red trace) show the presence of extra features at 228 and $465 \mathrm{~nm}$, assigned to $\mathrm{IO}_{3}{ }^{-}$and $\mathrm{IO}^{-}$, respectively; these are absent in cells cycled with the $\mathrm{IL}$ (Figure 4A, blue trace). The presence of $\mathrm{I}_{3}{ }^{-}$in both samples indicates that this is the main product of $\mathrm{I}^{-}$oxidation and therefore suggests that this is the species responsible for oxidizing $\mathrm{LiOH}$, rather than $\mathrm{I}_{2}$. The lack of $\mathrm{O}_{2}$ evolution observed in OER data of cells without $\mathrm{Pyr}_{14}$ TFSI can therefore be explained by the formation of oxidized iodine species $\left(\mathrm{IO}^{-}\right.$and $\left.\mathrm{IO}_{3}{ }^{-}\right)$, the oxygen effectively being trapped in the solution, as previously reported for similar electrolytes. ${ }^{14-16}$

The capability of $\mathrm{I}_{3}{ }^{-}$to oxidize $\mathrm{LiOH}$ during the OER was subsequently tested. A solution of $\mathrm{I}_{3}{ }^{-}$was injected into a mixture of electrolyte containing $700 \mathrm{mM} \mathrm{LiTFSI}$, $50 \mathrm{mM}$ Lil, $900 \mathrm{mM} \mathrm{Pyr}{ }_{14}$ TFSI, and 5,000 ppm H $\mathrm{H}_{2} \mathrm{O}$ in G4, and commercial LiOH powder. The subsequent gas evolution was measured by mass spectrometry (Figure 4B). Gas evolution from the $\mathrm{LiOH}$ powder, at $\mathrm{m} / \mathrm{z}=32$, can be directly observed as soon as the $\mathrm{I}_{3}{ }^{-}$solution is injected, confirming the evolution of $\mathrm{O}_{2}$ from this mixture and demonstrating that $\mathrm{I}_{3}{ }^{-}$is capable of oxidizing $\mathrm{LiOH}$ in this electrolyte; very little $\mathrm{O}_{2}$ evolution is observed in the absence of $\mathrm{Pyr}_{14}$ TFSI. 


\section{CellPress}

A

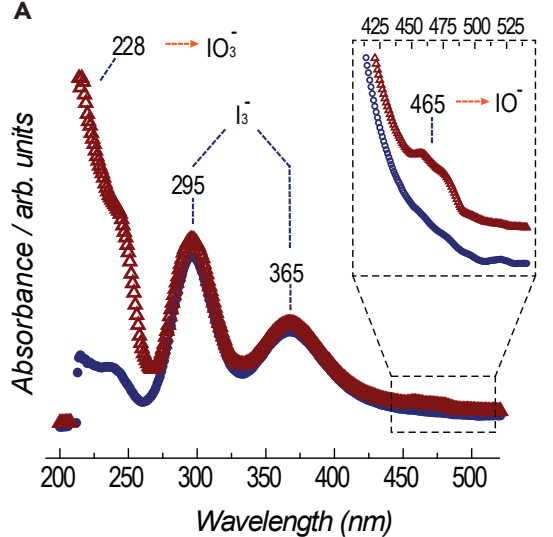

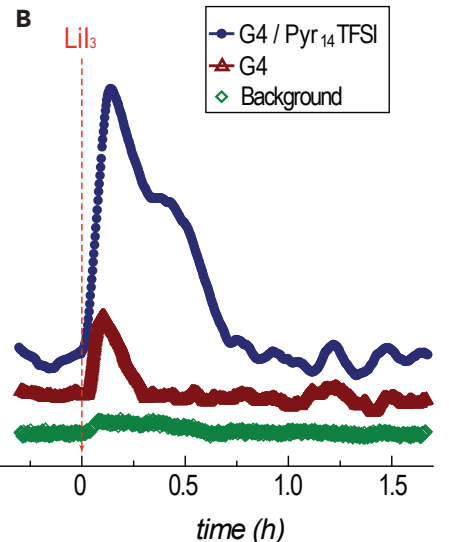

Figure 4. Spectroscopic and Electrochemical Analysis of the $\mathrm{I}_{3}{ }^{-}$Oxidizing Power

(A) UV spectra of catholytes collected after galvanostatic discharge and charge of cells containing $700 \mathrm{mM}$ LiTFSI, $50 \mathrm{mM}$ Lil, and 5,000 ppm H $\mathrm{H}_{2} \mathrm{O}$ (red trace) and with $900 \mathrm{mM} \mathrm{Pyr}_{14}$ TFSI (blue trace) in G4

(B) Online mass spectrometry test of the reaction of $\mathrm{I}_{3}{ }^{-}$with $\mathrm{LiOH}$. A $50 \mathrm{mM} \mathrm{I}_{3}{ }^{-}$solution is injected into a vessel containing LiOH powder immersed in electrolyte with $700 \mathrm{mM}$ LiTFSI, $50 \mathrm{mM}$ Lil, $900 \mathrm{mM} \mathrm{Pyr}{ }_{14}$ TFSI, and 5,000 ppm $\mathrm{H}_{2} \mathrm{O}$ in $\mathrm{G} 4$ (blue trace) and $700 \mathrm{mM} \mathrm{LiTFSI,} 50 \mathrm{mM}$ Lil, and 5,000 ppm $\mathrm{H}_{2} \mathrm{O}$ in G4 (red trace). The gas evolution of the ensuing reaction was recorded with a mass spectrometer $(\mathrm{m} / \mathrm{z}=32$, corresponding to $\mathrm{O}_{2}$ evolution is displayed). A blank spectrum was collected by injecting the $\mathrm{I}_{3}{ }^{-}$solution into the electrolyte containing $700 \mathrm{mM}$ LiTFSI, $50 \mathrm{mM}$ Lil, $900 \mathrm{mM} \mathrm{Pyr}{ }_{14}$ TFSI, and 5,000 ppm H $\mathrm{H}_{2} \mathrm{O}$ in G4 in the absence of LiOH (green trace). Argon was used as the carrier gas.

In order to assess the thermodynamic consistency of this reaction pathway, and whether the $\mathrm{I}^{-} / \mathrm{I}_{3}{ }^{-}$couple provides a sufficient driving force for the OER, the Gibbs free energy of the OER $\left(\Delta_{\mathrm{OER}} \mathrm{G}\right)$ was estimated according to Reaction 1:

$$
\begin{aligned}
& \Delta_{\mathrm{OER}} \mathrm{G}=2 \Delta_{\mathrm{f}} \mathrm{G}^{\circ}\left(\mathrm{H}_{2} \mathrm{O}\right)+\Delta_{\mathrm{f}} \mathrm{G}^{\circ}\left(\mathrm{O}_{2}\right)+4 \Delta_{\mathrm{f}} \mathrm{G}^{\circ}(\mathrm{Li})-4 \Delta_{\mathrm{f}} \mathrm{G}^{\circ}\left(\mathrm{OH}^{-}\right) \\
& \quad-4 \Delta_{\mathrm{f}} \mathrm{G}^{\circ}\left(\mathrm{Li}^{+}\right)+2 \Delta_{\text {sol }} \mathrm{G}\left(\mathrm{H}_{2} \mathrm{O}\right)+\Delta_{\mathrm{sol}} \mathrm{G}\left(\mathrm{O}_{2}\right)-4 \Delta_{\mathrm{sol}} \mathrm{G}\left(\mathrm{OH}^{-}\right)-4 \Delta_{\text {sol }} \mathrm{G}\left(\mathrm{Li}^{+}\right)
\end{aligned}
$$

(Equation 1)

The $\Delta_{\mathrm{OER}} G$ can then be written as the combination of Reactions 2 and 3 (the $\left(\mathrm{I}^{-} / \mathrm{I}_{3}{ }^{-}\right.$) redox pair, and the $\mathrm{OH}^{-} \rightarrow \mathrm{O}_{2}$ chemical reaction, respectively), giving the Gibbs free energy

$$
\Delta_{\mathrm{OER}} \mathrm{G}=2 \Delta_{\mathrm{r}} \mathrm{G}\left(\mathrm{I}^{-} / \mathrm{I}_{3}^{-}\right)+\Delta_{\mathrm{r}} \mathrm{G}\left(\mathrm{OH}^{-} \rightarrow \mathrm{O}_{2}\right),
$$

(Equation 2)

where $\Delta_{\mathrm{r}} \mathrm{G}\left(\mathrm{I}^{-} / \mathrm{I}_{3}^{-}\right)$is the Gibbs free energy of the $\mathrm{I}^{-} / \mathrm{I}_{3}^{-}$redox couple, defined as

$\Delta_{\mathrm{r}} \mathrm{G}\left(\mathrm{I}^{-} / \mathrm{I}_{3}^{-}\right)=\Delta_{\mathrm{f}} \mathrm{G}^{0}\left(\mathrm{I}_{3}^{-}\right)+2 \Delta_{\mathrm{f}} \mathrm{G}^{0}(\mathrm{Li})-2 \Delta_{\mathrm{f}} \mathrm{G}^{0}\left(\mathrm{Li}^{+}\right)-3 \Delta_{\mathrm{f}} \mathrm{G}^{\circ}\left(\mathrm{I}^{-}\right)+\Delta_{\text {sol }} \mathrm{G}\left(\mathrm{I}_{3}^{-}\right)-2 \Delta_{\text {sol }} \mathrm{G}\left(\mathrm{Li}^{+}\right)$ $-3 \Delta_{\text {sol }} \mathrm{G}\left(I^{-}\right)$,

(Equation 3)

and $\Delta_{\mathrm{r}} \mathrm{G}\left(\mathrm{OH}^{-} \rightarrow \mathrm{O}_{2}\right)$ is the Gibbs free energy of the $\mathrm{OH}^{-} \rightarrow \mathrm{O}_{2}$ chemical reaction, defined as

$$
\begin{aligned}
& \Delta_{\mathrm{r}} \mathrm{G}\left(\mathrm{OH}^{-} \rightarrow \mathrm{O}_{2}\right)=6 \Delta_{\mathrm{f}} \mathrm{G}^{\circ}\left(\mathrm{I}^{-}\right)+2 \Delta_{\mathrm{f}} \mathrm{G}^{\circ}\left(\mathrm{H}_{2} \mathrm{O}\right)+\Delta_{\mathrm{f}} \mathrm{G}^{\circ}\left(\mathrm{O}_{2}\right)-4 \Delta_{\mathrm{f}} \mathrm{G}^{\circ}\left(\mathrm{OH}^{-}\right) \\
& \quad-2 \Delta_{\mathrm{f}} \mathrm{G}^{\circ}\left(\mathrm{I}_{3}^{-}\right)+6 \Delta_{\mathrm{sol}} \mathrm{G}\left(\mathrm{I}^{-}\right)+2 \Delta_{\mathrm{sol}} \mathrm{G}\left(\mathrm{H}_{2} \mathrm{O}\right)+\Delta_{\mathrm{sol}} \mathrm{G}\left(\mathrm{O}_{2}\right)-4 \Delta_{\mathrm{sol}} \mathrm{G}\left(\mathrm{OH}^{-}\right)-2 \Delta_{\mathrm{sol}} \mathrm{G}\left(\mathrm{I}_{3}^{-}\right) .
\end{aligned}
$$

(Equation 4)

$\Delta_{\mathrm{OER}} \mathrm{G}$ depends on the Gibbs free energy of formation of $\mathrm{H}_{2} \mathrm{O}\left(\Delta_{\mathrm{f}} \mathrm{G}^{\circ}\left(\mathrm{H}_{2} \mathrm{O}\right)\right), \mathrm{O}_{2}$ $\left(\Delta_{\mathrm{f}} \mathrm{G}^{\circ}\left(\mathrm{O}_{2}\right)\right)$, Li $\left(\Delta_{\mathrm{f}} \mathrm{G}^{\circ}(\mathrm{Li})\right), \mathrm{OH}^{-}\left(\Delta_{\mathrm{f}} \mathrm{G}\left(\mathrm{OH}^{-}\right)\right)$, and $\mathrm{Li}^{+}\left(\Delta_{\mathrm{f}} \mathrm{G}^{\circ}\left(\mathrm{Li}^{+}\right)\right)$at standard conditions, and their Gibbs free energy of solvation, $\left(\Delta_{\text {sol }} \mathrm{G}\left(\mathrm{H}_{2} \mathrm{O}\right), \Delta_{\text {sol }} \mathrm{G}\left(\mathrm{O}_{2}\right), \Delta_{\text {sol }} \mathrm{G}(\mathrm{Li})\right.$, $\Delta_{\text {sol }} \mathrm{G}\left(\mathrm{OH}^{-}\right)$, and $\Delta_{\text {sol }} \mathrm{G}\left(\mathrm{Li}^{+}\right)$), which are solvent specific. $\Delta_{\mathrm{f}} \mathrm{G}^{\circ}\left(\mathrm{H}_{2} \mathrm{O}\right)$ and $\Delta_{\mathrm{f}} \mathrm{G}^{\circ}\left(\mathrm{O}_{2}\right)$ are tabulated values, ${ }^{41}$ whereas, by definition, $\Delta_{\mathrm{f}} \mathrm{G}^{\circ}(\mathrm{Li})=0$. Using the Nernst 
equation for the $\mathrm{I}^{-} / \mathrm{I}_{3}^{-}$redox couple, and assuming that the dissolved oxygen $\left(\mathrm{O}_{2(\mathrm{sol})}\right)$ is at equilibrium with oxygen gas $\left(\mathrm{O}_{2(\mathrm{~g})}\right)$ at a pressure $\left(\mathrm{P}_{\mathrm{O}_{2}}\right)$ and that the oxygen can be treated as an ideal gas over the range of temperature concerned (see Supplemental Information), the above expression can be written as:

$$
\begin{aligned}
& \Delta_{\mathrm{r}} \mathrm{G}\left(\mathrm{OH}^{-} \rightarrow \mathrm{O}_{2}\right)=2 \Delta_{\mathrm{f}} \mathrm{G}^{\circ}\left(\mathrm{H}_{2} \mathrm{O}\right) \\
& \quad-4 \Delta_{\mathrm{f}} \mathrm{G}^{\circ}(\mathrm{LiOH})+2 \mathrm{nFE}\left(\mathrm{I}^{-} / \mathrm{I}_{3}^{-}\right)+2 \Delta_{\mathrm{sol}} \mathrm{G}\left(\mathrm{H}_{2} \mathrm{O}\right)+\mathrm{kT} \ln \left(\frac{\mathrm{P}_{\mathrm{O}_{2}}}{\mathrm{P}^{\circ}}\right) . \quad \text { (Equation 5) }
\end{aligned}
$$

This expression indicates that three key variables dictate the driving force for the OER: the redox equilibrium potential of the $\mathrm{I}^{-} / \mathrm{I}_{3}{ }^{-}$couple $\left(\mathrm{E}\left(\mathrm{I}^{-} / \mathrm{I}_{3}^{-}\right)\right)$, the water activity $\left(\Delta_{\text {sol }} \mathrm{G}\left(\mathrm{H}_{2} \mathrm{O}\right)\right.$ ), and the oxygen partial pressure $\left(\mathrm{P}_{\mathrm{O}_{2}}\right)$. The redox potential of the iodide/triiodide redox system is solvent dependent, ${ }^{18-20}$ the couple varying by over $0.5 \mathrm{~V},{ }^{18}$ whereas variations in the solvent activity and gas partial pressure are of smaller magnitude (estimated to be $\sim 0.17$ and $\sim 0.08 \mathrm{eV}$, respectively; Table S2). The variability in the values of the $\mathrm{E}\left(\mathrm{I}^{-} / \mathrm{I}_{3}^{-}\right)$is strongly influenced by stabilizing (donor-acceptor) interactions of $\mathrm{I}^{-}$species in solution, ${ }^{18,20}$ since $\Delta_{\mathrm{r}} \mathrm{G}\left(\mathrm{I}^{-} / \mathrm{I}_{3}^{-}\right)$is proportional to the difference in $\Delta_{\mathrm{sol}} \mathrm{G}$ of $\mathrm{I}^{-}$and $\mathrm{I}_{3}{ }^{-}$:

$$
\Delta_{\mathrm{r}} \mathrm{G}\left(\mathrm{I}^{-} / \mathrm{I}_{3}^{-}\right) \propto \Delta_{\mathrm{sol}} \mathrm{G}\left(\mathrm{I}_{3}^{-}\right)-3 \Delta_{\mathrm{sol}} \mathrm{G}\left(\mathrm{I}^{-}\right) \quad \text { (Equation 6) }
$$

The OEMS results presented in Figures 1, 3, and 4 suggest that the addition of $\mathrm{Pyr}_{14}$ TFSI (alongside small amounts of water) is capable of increasing the oxidizing power of $\mathrm{I}_{3}{ }^{-}$and/or reducing the couple of the OER sufficiently so that it can occur below $3.5 \mathrm{~V}$. We now turn to identify and rationalize the effect of the additives (water, $\mathrm{IL}$ ) on the redox equilibrium potential of the $\mathrm{I}^{-} / \mathrm{I}_{3}{ }^{-}$couple.

\section{Modification of the $\mathrm{I}^{-} / \mathrm{I}_{3}^{-}$Redox Potential}

Effect of the Additives on the Coordination of $\mathrm{I}^{-}$and on the OER. It has recently been shown that water and ILs are among the media in which $E\left(I^{-} / I_{3}^{-}\right)$has the highest values, due to the very strong coordination of $\mathrm{I}^{-}$by these solvent molecules: ${ }^{18}$ water molecules, for example, solvating $\mathrm{I}^{-}$ions via hydrogen-halogen bonds within the $\mathrm{I}^{-}$first solvation shell. In order to investigate the effect of the additives used here, we have explored potential correlations between the ${ }^{1} \mathrm{H}-\mathrm{NMR}$ chemical shift of the water peak and the $\mathrm{I}^{-} / \mathrm{I}_{3}{ }^{-}$redox potential (Figure 5). The addition of 5,000 ppm of water to an electrolyte with no IL (700 mM LiTFSI, $50 \mathrm{mM}$ Lil in G4) increases $\mathrm{E}\left(\mathrm{I}^{-} / \mathrm{I}_{3}^{-}\right)$by only $\sim 0.01 \mathrm{~V}$ (Figure $\left.5 \mathrm{D}\right)$. ${ }^{1} \mathrm{H}-\mathrm{NMR}$ spectra of the same electrolyte with increasing amounts of water (Figure $5 \mathrm{~F}$ ) are consistent with prior work: ${ }^{11}$ at low water concentrations, a peak is observed at high frequencies, consistent with strong $\mathrm{H}_{2} \mathrm{O}: \mathrm{I}^{-}$interactions. The chemical shift is slightly lower than that of bulk water, as this effect is less significant than the shift arising from $\mathrm{H}$-bonding interactions between water molecules. As the water concentration increases for a fixed Lil content, the peak shifts from 4.45 to 4.35 ppm again indicating weaker $\mathrm{H}_{2} \mathrm{O}: \mathrm{I}^{-}$interactions. In previous work, ${ }^{11}$ the trend was then seen to reverse at higher water concentrations of $>5 \% \mathrm{H}_{2} \mathrm{O}$ (and $50 \mathrm{mM}$ Lil) due to the strong hydrogen bonding interactions in between molecules in water clusters, resulting in a shift toward the position of bulk water.

The progressive addition of $\mathrm{Pyr}_{14} \mathrm{TFSI}$ to the electrolyte containing 5,000 ppm of water (700 mM LiTFSI, 50 mM Lil in G4) shows a similar trend in the ${ }^{1} \mathrm{H}$-NMR spectra (Figures 5A, 5B, and S16), with the water peak shifting downfield even further from 4.35 to $4.1 \mathrm{ppm}$ on addition of $900 \mathrm{mM} \mathrm{Pyr}{ }_{14} \mathrm{TFSI}$, suggesting either reduced $\mathrm{H}_{2} \mathrm{O}: \mathrm{I}^{-}$interactions and/or reduced $\mathrm{H}_{2} \mathrm{O} \mathrm{H}$-bonding. In both scenarios, this indicates an increased "solvation" of the water and I- by the IL. This increase in Pyr ${ }_{14}$ TFSI concentration also has a large associated increase in the $\mathrm{I}^{-} / \mathrm{I}_{3}{ }^{-}$redox potential, from 

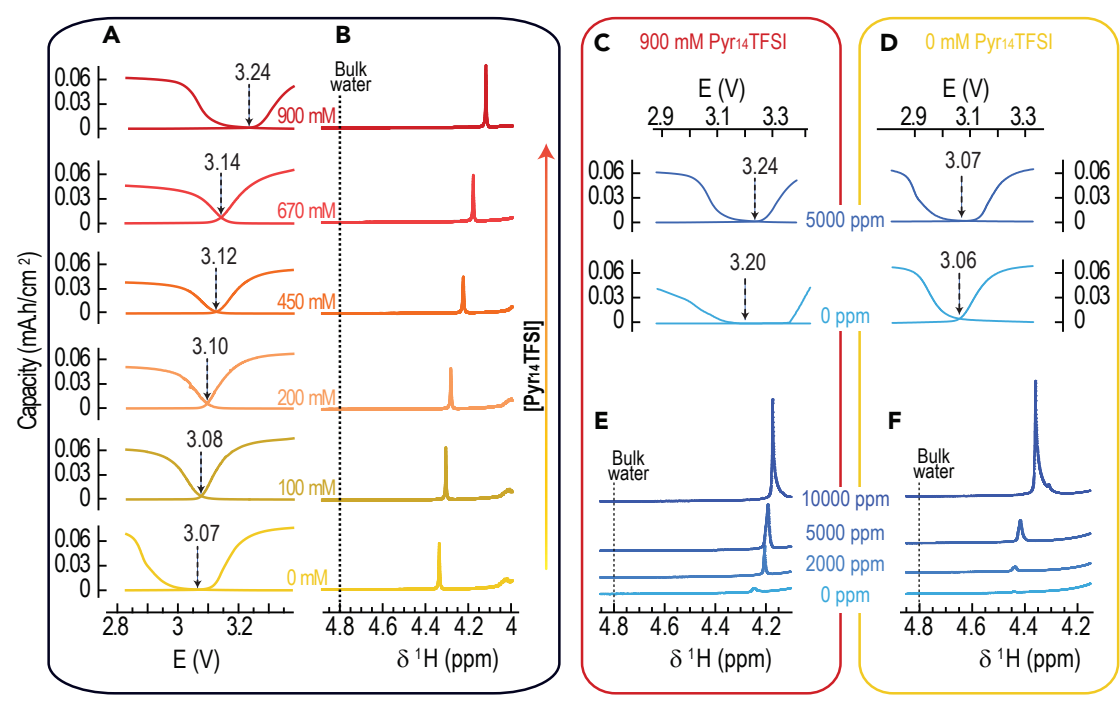

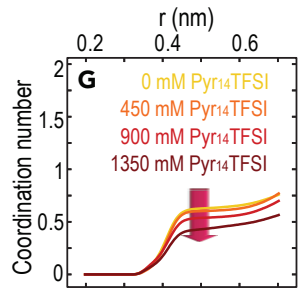

$I^{-}-\mathrm{H}_{2} \mathrm{O}$
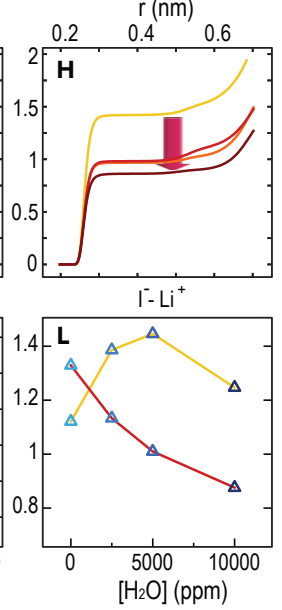

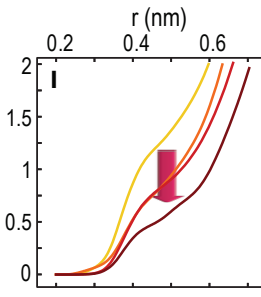

I- G4

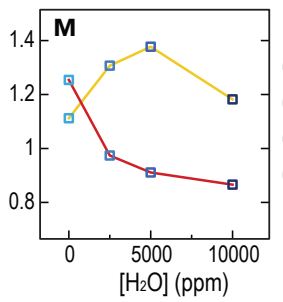

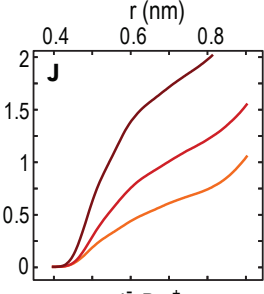

$I^{-}-$Pyr $_{14}^{+}$

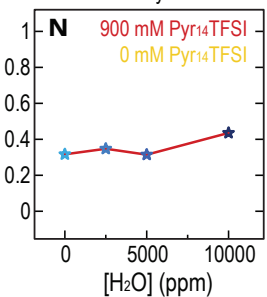

Figure 5. Correlation between Water Chemical Shift and $\mathrm{I}^{-} / \mathrm{I}_{3}{ }^{-}$Equilibrium Redox Potential (A and B) Effect of $\mathrm{Pyr}_{14}$ TFSI concentration $(0-900 \mathrm{mM})$ on (A) galvanostatic charge-discharge curves, and (B) solution ${ }^{1} \mathrm{H}-\mathrm{NMR}$ of $700 \mathrm{mM} \mathrm{LiTFSI}, 50 \mathrm{mM} \mathrm{Lil,} \mathrm{and} \mathrm{5,000} \mathrm{ppm} \mathrm{H}_{2} \mathrm{O}$ in $\mathrm{G} 4$ electrolyte. ( $C$ and $D$ ) Effect of water concentration (0 versus 5,000 ppm) on galvanostatic charge-discharge curves of electrolytes with (C) $900 \mathrm{mM}$ and (D) $0 \mathrm{mM} \mathrm{Pyr}{ }_{14}$ TFSI.

(E and F) Solution ${ }^{1} \mathrm{H}-\mathrm{NMR}$ of electrolytes with increasing amounts of water with (E) $900 \mathrm{mM}$ and (F) $0 \mathrm{mM}$ Pyr $_{14}$ TFSI.

(G-J) MD coordination number (CN) plots of the $\mathrm{I}^{-}$center of mass to $(\mathrm{G}) \mathrm{H}_{2} \mathrm{O},(\mathrm{H}) \mathrm{Li}^{+}$, (I) G4, and (J) $\mathrm{Pyr}_{14}{ }^{+}$as a function of distance for 5,000 ppm H $\mathrm{H}_{2} \mathrm{O}$ in $700 \mathrm{mM} \mathrm{LiTFSI}, 50 \mathrm{mM}$ Lil, in G4 electrolyte with increasing amounts of Pyr $\mathrm{r}_{14}$ TFSI $(0-1,350 \mathrm{mM})$.

$(\mathrm{K}-\mathrm{N})$ Evolution of the $\mathrm{I}^{-} \mathrm{CN}$ in the first coordination shell to $(\mathrm{K}) \mathrm{H}_{2} \mathrm{O},(\mathrm{L}) \mathrm{Li}^{+},(\mathrm{M}) \mathrm{G} 4$, and (N) Pyr $14{ }^{+}$ (measured at $0.5 \mathrm{~nm}$ for $\mathrm{H}_{2} \mathrm{O}, \mathrm{Li}^{+}$, and $\mathrm{G} 4$ and at $0.7 \mathrm{~nm}$ for $\mathrm{Pyr}_{14}{ }^{+}$) as a function of $\left[\mathrm{H}_{2} \mathrm{O}\right]$ in electrolytes with $0 \mathrm{mM} \mathrm{Pyr}{ }_{14}$ TFSI (yellow lines) and $900 \mathrm{mM} \mathrm{Pyr}{ }_{14}$ TFSI (red lines). All galvanostatic cycling was performed at $50 \mu \mathrm{A} / \mathrm{cm}^{2}$ under argon in cells containing a LICGC. $300 \mathrm{mM}$ LiTFSI in G4 was used as the anolyte.

3.07 to $3.24 \mathrm{~V}(\sim 0.17 \mathrm{~V})$, consistent with the strong interaction between $\mathrm{I}^{-}$and $\mathrm{Pyr}_{14}{ }^{+}$ (also shown in CV data in Figure S15). The largest value of $\mathrm{E}\left(\mathrm{I}^{-} / \mathrm{I}_{3}^{-}\right)$is observed when Pyr ${ }_{14}$ TFSI is present, the effect on the $\mathrm{I}^{-} / \mathrm{I}_{3}{ }^{-}$coupling of adding $\mathrm{Pyr}_{14}{ }^{+}$being stronger than the addition of 5,000 ppm of water as shown in Figures $5 \mathrm{C}$ and 5D. A smaller shift in the ${ }^{1} \mathrm{H}$ resonance is observed upon increasing water concentration (between 2,000 and 5,000 ppm) in the presence of $\operatorname{Pyr}_{14} \operatorname{TFSI}(\Delta \delta=-0.03 \mathrm{ppm}$; Figure 5E) than 
in its absence ( $\Delta \boldsymbol{\delta}=-0.08$ ppm; Figure $5 \mathrm{~F}$ ), which is indicative of weaker water- $\mathrm{I}^{-}$interactions in the presence of the IL. This reduced water- $\mathrm{I}^{-}$interaction and the higher measured $\mathrm{E}\left(\mathrm{I}^{-} / \mathrm{I}_{3}^{-}\right)$suggest that the $\mathrm{Pyr}_{14}{ }^{+}$cation may be a stronger coordinating agent for $\mathrm{I}^{-}$ions than water under the conditions used here. The larger ${ }^{1} \mathrm{H}$ shifts of the water peak observed in pure $\mathrm{Pyr}_{14}$ TFSI, compared to the mixtures shown in Figure 5 (Figure S17), is in agreement with a synergistic coordination effect of both water and $\mathrm{Pyr}_{14}$ TFSI toward $\mathrm{I}^{-}$. This is in agreement with the hard and soft acids and bases (HSAB) concept, ${ }^{42}$ since the introduction of the $\mathrm{Pyr}_{14}{ }^{+}$cation, a softer Lewis base than $\mathrm{Li}^{+}$and $\mathrm{H}^{+}$(the other cations present in the electrolyte), would be expected to have a strong impact on the coordination of $\mathrm{I}^{-}$, which is a soft Lewis acid.

In order to investigate the effects of the additives on the coordination of $\mathrm{I}^{-}$, MD simulations were performed. Figures $5 \mathrm{G}-5 \mathrm{~L}$ show the average coordination number $(\mathrm{CN})$ of $\mathrm{I}^{-}$to different species as a function of distance. The increase in $\mathrm{Pyr}_{14} \mathrm{TFSI}_{\mathrm{T}}$ concentration reduces the contributions in the first $\mathrm{I}^{-}$coordination shell from $\mathrm{H}_{2} \mathrm{O}$ (Figure $5 \mathrm{G}$ ), $\mathrm{Li}^{+}$ (Figure 5H), and G4 (Figure 5K), while the contribution from $\mathrm{Pyr}_{14}{ }^{+}$increases (Figure $5 \mathrm{~L}$ ). The MD results are consistent with the ${ }^{1} \mathrm{H}-\mathrm{NMR}$ results, the increase in the $\mathrm{H}_{2} \mathrm{O}$ molecules in the first coordination shell of $\mathrm{I}^{-}$with increasing water concentration (Figure 5M) correlating with the shift of the water ${ }^{1} \mathrm{H}-\mathrm{NMR}$ peak to lower values in both the absence (Figure 5F) and the presence of the IL (Figure 5E). The smaller chemical shift of the ${ }^{1} \mathrm{H}$-NMR water peak observed in the presence of $\mathrm{Pyr}_{14} \mathrm{TFSI}$ is correlated with a smaller increase of $\mathrm{H}_{2} \mathrm{O}$ molecules in the first coordination shell of $\mathrm{I}^{-}$(Figure $5 \mathrm{M}$ ). This effect has further implications on the coordination of $\mathrm{I}^{-}$by $\mathrm{Li}^{+}$and $\mathrm{G} 4$ : the number of $\mathrm{I}^{-}-\mathrm{Li}^{+}$(Figure $5 \mathrm{H}$ ) and $\mathrm{G}^{-} \mathrm{I}^{-}$(Figure $5 \mathrm{~K}$ ) interactions in the first coordination shell of $\mathrm{I}^{-}$decreases with increasing water content (up to $5,000 \mathrm{ppm}$ ) in the absence of IL. However, the presence of IL ( $900 \mathrm{mM}$ ) reverses this effect, and both $\mathrm{Li}^{+}$(Figure $5 \mathrm{H}$ ) and $\mathrm{G} 4$ (Figure 5K) are on average increasingly present in the first coordination shell of $\mathrm{I}^{-}$with increasing water content. This indicates a fundamentally different contribution of the IL to the solvation of $\mathrm{I}^{-}$compared to water and corroborates the complex interplay between the two additives used in the electrolyte capable of undergoing OER during $\mathrm{LiOH}$ oxidation (Figure 1).

The disruptive insertion of $\mathrm{Pyr}_{14}{ }^{+}$ions into the first coordination shell of $\mathrm{I}^{-}$can be clearly visualized in snapshots of the final state of the simulations of electrolytes with increasing $\mathrm{Pyr}_{14}$ TFSI concentrations shown in Figures 6A-6D. The comparative levels of coordination of $\mathrm{Li}^{+}, \mathrm{H}_{2} \mathrm{O}, \mathrm{G} 4$, and $\mathrm{Pyr}_{14}{ }^{+}$ions, evaluated as a function of the concentration of $\mathrm{Pyr}_{14}$ TFSI (Figure 6E), indicate a strong $\mathrm{Pyr}_{14}{ }^{+}-\mathrm{I}^{-}$interaction, to levels comparable to that of $\mathrm{Li}^{+}$and $\mathrm{H}_{2} \mathrm{O}$ at $\left[\mathrm{Pyr}_{14}\right.$ TFSI] $=900 \mathrm{mM}$, in agreement with previous MD studies. ${ }^{16,18}$ This complex interplay is also reflected on the mobility of $\mathrm{I}^{-}$ions (their mean squared displacement) in the electrolyte (Figure 6F). In the absence of IL, $\mathrm{I}^{-}$mobility is not strongly affected by increasing amounts of water (solid lines) up to 10,000 ppm. The presence of $900 \mathrm{mM}$ of $\mathrm{Pyr}_{14} \mathrm{TFSI}$ in neat electrolytes reduces $\mathrm{I}^{-}$ion mobility compared to the electrolyte with no IL (light blue traces). However, the presence of $\mathrm{Pyr}_{14}$ TFSI has the effect of substantially increasing $\mathrm{I}^{-}$ion mobility with increasing water content up to 5,000 ppm. At higher water content, the mobility is reduced to some extent due to the onset of water clusters formation. ${ }^{11}$ The electrolyte mixture used in the cell reported in Figure $1(900 \mathrm{mM}$ Pyr ${ }_{14}$ TFSI and 5,000 ppm of water) has similar average amounts of $\mathrm{Li}^{+}, \mathrm{G} 4$, and $\mathrm{Pyr}_{14}{ }^{+}$in the first coordination shell of $\mathrm{I}^{-}$(Figure 6E), and it has the highest measured $\mathrm{I}^{-}$mobility (Figure 6F).

Thermodynamic Analysis of the Effect of Additives. The measurements of the $\mathrm{I}^{-} /$ $\mathrm{I}_{3}{ }^{-}$redox potential shown in Figure $5 \mathrm{~A}$ allow us to estimate the effect of the additives 

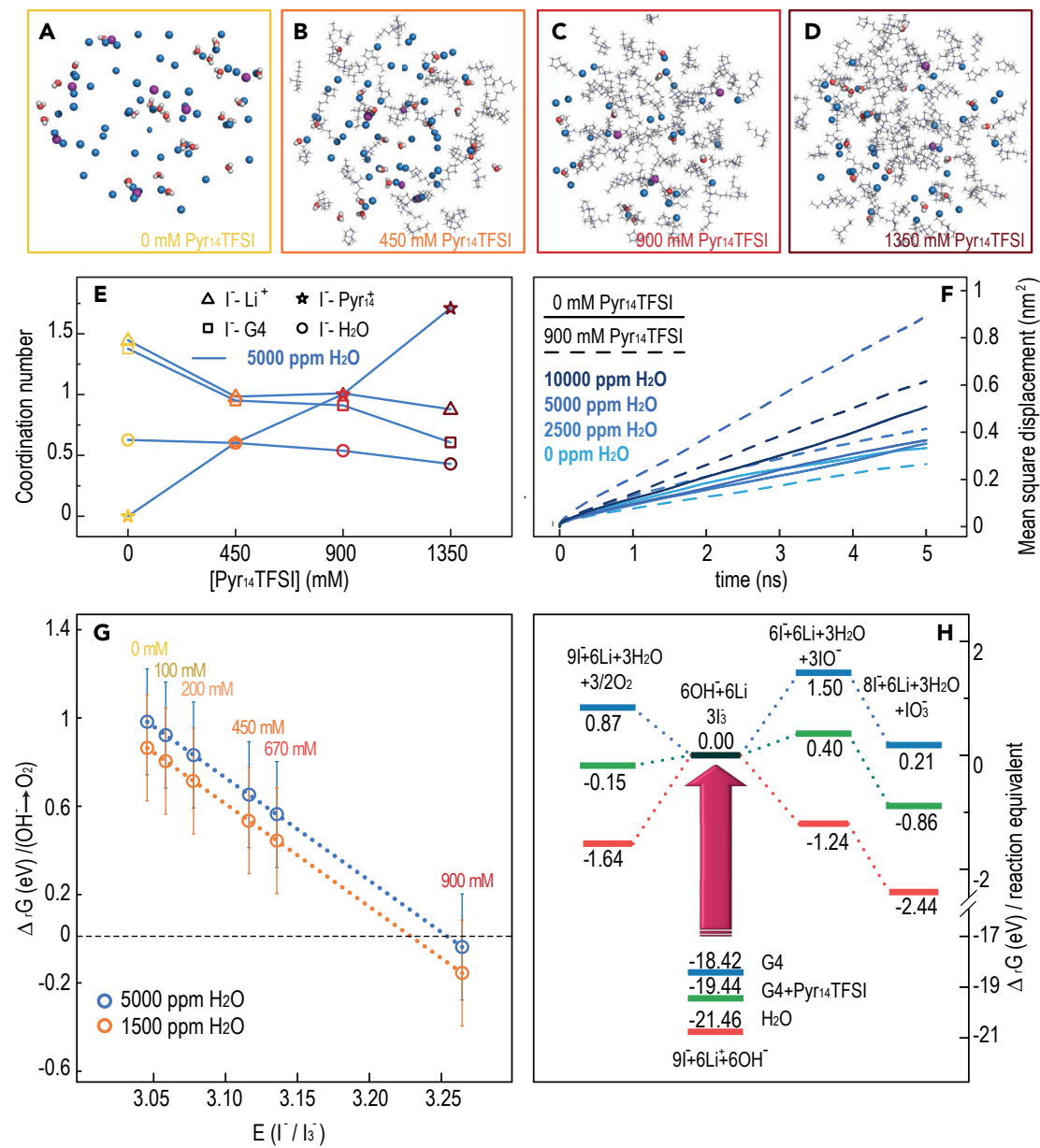

Figure 6. MD Simulations of Electrolytes with Varying Levels of Additives; Implications for the Thermodynamic Drive for the OER

(A-D) Snapshots of the final state of the simulations of electrolytes containing $700 \mathrm{mM}$ LiTFSI, $50 \mathrm{mM} \mathrm{Lil}$, and 5,000 ppm H $\mathrm{H}_{2} \mathrm{O}$ in G4 with (A) 0 mM, (B) $450 \mathrm{mM}$, (C) $900 \mathrm{mM}$, and (D) 1,200 mM Pyr ${ }_{14}$ TFSI showing I- (magenta), $\mathrm{Li}^{+}$(blue), $\mathrm{H}_{2} \mathrm{O}$ (red/white), and $\mathrm{Pyr}_{14}{ }^{+}$(sticks). $\mathrm{G} 4$ molecules are omitted for clarity.

(E) Plot of the evolution of the $\mathrm{CN}$ in the first coordination shell of $\mathrm{I}^{-}$to $\mathrm{H}_{2} \mathrm{O}, \mathrm{Li}^{+}, \mathrm{G} 4$, and $\mathrm{Pyr}_{14}{ }^{+}$with increasing $\mathrm{Pyr}_{14}$ TFSI concentration in electrolytes containing 5,000 ppm $\mathrm{H}_{2} \mathrm{O}$.

(F) Mean square displacement of $\mathrm{I}^{-}$ions in electrolytes with $0 \mathrm{mM} \mathrm{Pyr}{ }_{14}$ TFSI (solid lines) and $900 \mathrm{mM}$ Pyr $_{14}$ TFSI (dashed lines) with increasing water concentration.

(G) Effect of the various $\mathrm{E}\left(\mathrm{I}^{-} / \mathrm{I}_{3}{ }^{-}\right.$) couples measured for different $\mathrm{Pyr}_{14} \mathrm{TFSI}$ concentrations (shown in Figure 5A) on the thermodynamic driving force for the OER, assuming 5,000 ppm (end of charge, blue) and 1,500 ppm of water (beginning of charge, orange). The error bars are calculated based on the assumptions made in the calculations (see Supplemental Information).

(H) Free-energy diagram for the proposed mechanisms involving the iodide-mediated $\mathrm{LiOH}$ oxidation $\left(\mathrm{O}_{2}\right.$ evolution [left], $\mathrm{IO}^{-}$and $\mathrm{IO}_{3}{ }^{-}$formation [right], relative to $\mathrm{I}_{3}{ }^{-}$formation in $\mathrm{G} 4$ [blue], $\mathrm{G} 4+900 \mathrm{mM} \mathrm{Pyr}{ }_{14} \mathrm{TFSI}$ [green], and $\mathrm{H}_{2} \mathrm{O}$ [red]). The Gibbs free-energy values were calculated for the electrolytes containing 700 $\mathrm{mM}$ LiTFSI, $50 \mathrm{mM}$ Lil, and 5,000 ppm H ${ }_{2} \mathrm{O}$ in G4 with $0 \mathrm{mM}$ and $900 \mathrm{mM} \mathrm{Pyr}{ }_{14} \operatorname{TFSI}\left(\mathrm{E}\left(\mathrm{I}^{-} / \mathrm{I}_{3}{ }^{-}\right)=3.07 \mathrm{~V}\right.$ and 3.24 $\mathrm{V}$, respectively; Figure $5 \mathrm{~A}$ ) and in standard conditions. All electrochemical reactions are scaled to $6 \mathrm{e}^{-}$so as to compare the free energies of the various reactions.

used in this work on the thermodynamic drive of the OER using Equation 5. Figure 6G shows an estimation of $\Delta_{\mathrm{r}} \mathrm{G}\left(\mathrm{OH}^{-} \rightarrow \mathrm{O}_{2}\right)$ as a function of the $\mathrm{I}^{-} / \mathrm{I}_{3}{ }^{-}$redox potential in electrolyte mixtures with increasing $\mathrm{Pyr}_{14}$ TFSI concentration for two levels of $\mathrm{H}_{2} \mathrm{O}$ concentration (1,500 ppm [orange] and 5,000 ppm [blue], representing the theoretical levels at the beginning and end of the charge, respectively). The calculation of 
the thermodynamic drive of the OER has been scaled up to $6 \mathrm{e}^{-}$(instead of the $4 \mathrm{e}^{-}$ process described above) in order to allow direct comparison with the formation of $\mathrm{IO}^{-}$and $\mathrm{IO}_{3}^{-}$(Figure $6 \mathrm{H}$ ). It can be seen that only at a $\mathrm{I}^{-} / \mathrm{I}_{3}^{-}$redox potential above $\sim 3.24 \mathrm{~V}$ does the OER becomes thermodynamically favorable, with $\Delta_{\mathrm{r}} \mathrm{G}\left(\mathrm{OH}^{-} \rightarrow \mathrm{O}_{2}\right)$ $\approx-0.03 \mathrm{eV}( \pm 0.24)$ for $\left[\mathrm{Pyr}_{14} \mathrm{TFSI}\right]=900 \mathrm{mM}$ at $5,000 \mathrm{ppm} \mathrm{H}_{2} \mathrm{O}$ and $\approx-$ $0.15 \mathrm{eV}( \pm 0.24)$ at $1,500 \mathrm{ppm} \mathrm{H}_{2} \mathrm{O}$ (see Supplemental Information for details). These values are very close to, or below, zero at equilibrium conditions, within the error margins arising from the assumptions made in the calculations and the measurement limitations, and thus this process is energetically feasible considering the experimental conditions (see Tables S1-S4 and Figure S22). It is of course important to note that during the charge the cell is working under non-equilibrium conditions, where the $\left[\mathrm{I}_{3}^{-}\right]$is higher and $\left[\mathrm{I}^{-}\right]$lower than under equilibrium conditions, providing an additional driving the force for the OER. The high values of $\mathrm{E}\left(\mathrm{I}^{-} / \mathrm{I}_{3}^{-}\right)$ observed in the electrolytes containing Pyr $_{14}$ TFSI and water can therefore provide a rationale for the observation of $\mathrm{O}_{2}$ evolution during the charge process shown in Figures $1 \mathrm{~A}-1 \mathrm{~F}$.

\section{OER versus $\mathrm{IO}_{3}^{-}$Formation}

Our results (Figure 1) indicate that there is a very fine balance between the production of $\mathrm{LilO}_{3}$ and $\mathrm{O}_{2}$, which we now discuss. The ability of $\mathrm{I}_{3}{ }^{-}$to oxidize $\mathrm{LiOH}$ to form $\mathrm{LilO}_{3}$ (via Reactions 5 and 6 ) has been found to be dependent on the Gutmann acceptor number (AN) of the solvent used, with $\mathrm{I}_{3}{ }^{-}$in $\mathrm{N}, \mathrm{N}$-dimethylacetamide (DMA), dimethyl sulfoxide (DMSO), and 1-methylimidazole (Me-Im) being capable of oxidizing $\mathrm{LiOH}$ (for AN > 13.6), but $\mathrm{I}_{3}{ }^{-}$in $\mathrm{G} 1, \mathrm{G} 4$, and pyridine being unable to. ${ }^{19}$ In the absence of water, a Lil-containing electrolyte in diethylene glycol dimethyl ether (G2) requires potentials above the $\mathrm{I}_{3}{ }^{-} / \mathrm{I}_{2}$ to remove $\mathrm{LiOH}$ from preloaded electrodes, ${ }^{19}$ whereas the formation of $\mathrm{IO}_{3}{ }^{-}$was reported in a LiOH-saturated G1-based electrolyte containing water (3wt\%). ${ }^{11,43}$ Electrochemically, several groups have reported the formation of $\mathrm{IO}^{-} / \mathrm{IO}_{3}{ }^{-}$during the charge of $\mathrm{LiOH}$-based $\mathrm{Li}_{2} \mathrm{O}_{2}$ cells in glyme electrolytes containing water and iodide, ${ }^{12,14,15,43}$ whereas in the absence of water, a charging plateau above the $\mathrm{I}_{3}{ }^{-} / \mathrm{I}_{2}$ redox transition was reportedly required in G2 ${ }^{19}$ (Figure S21). Our studies clearly show that the addition of small quantities of water increases the $\mathrm{I}_{3}{ }^{-}$oxidative power and that it can oxidize $\mathrm{LiOH}$ under these conditions: during galvanostatic charge of cells with $50 \mathrm{mM}$ Lil and 5,000 ppm $\mathrm{H}_{2} \mathrm{O}$ in $\mathrm{G} 4$ (Figures $1 \mathrm{G}-1 \mathrm{M}$ ), the charge process is observed to commence below the $\mathrm{I}_{3}{ }^{-} / \mathrm{I}_{2}$ transition (from as low as $3.2 \mathrm{~V}$ ). The detection of $\mathrm{IO}^{-}$and $\mathrm{IO}_{3}{ }^{-}$in the $\mathrm{UV}$ spectra (Figure $4 \mathrm{~A}$ ) is therefore consistent with $\mathrm{LiOH}$ removal via Reactions 5 and 6.

It has recently been argued that $\mathrm{LilO}_{3}$ is the thermodynamic product, rather than $\mathrm{O}_{2}$, on oxidation of $\mathrm{Li}_{2} \mathrm{O}_{2}$ by $\mathrm{I}_{3}{ }^{-}$, even though $\mathrm{O}_{2}$ evolution is seen. The reported lack of $\mathrm{LilO}_{3}$ formation was ascribed in this study to the slow kinetics of O-O dissociation needed to form $\mathrm{IO}^{-}$(and subsequently $\mathrm{LilO}_{3}$ ), even in solvents with low Gutmann AN, such as $\mathrm{G} 4$, where the decomposition of $\mathrm{Li}_{2} \mathrm{O}_{2}$ is very slow. ${ }^{19}$ The authors similarly argued that the most thermodynamically favorable route for the oxidation of $\mathrm{LiOH}$ occurs through the formation of $\mathrm{LilO}_{3}$ (Reactions 5 and 6) rather than the formation of $\mathrm{O}_{2}$ (Reaction 2). Our results motivate the same question as raised previously for $\mathrm{O}_{2}$ evolution from $\mathrm{Li}_{2} \mathrm{O}_{2}$ in the presence of Lil: the presence of $\mathrm{Pyr}_{14}$ TFSI increases the oxidizing power of $\mathrm{I}_{3}{ }^{-}$so that it can promote $\mathrm{O}_{2}$ evolution, but why does it also disfavor the $\mathrm{IO}_{3}{ }^{-}$formation mechanism?

We now consider the thermodynamic driving force to form lithium iodate $\left(\mathrm{IO}_{3}{ }^{-}\right)$ in basic media via an analogous analysis to the $\mathrm{LiOH}$ oxidation, through the $\mathrm{I}^{-}$-mediated OER described above. Starting with the following reaction (full derivation is found in the Supplemental Information): 


$$
6 \mathrm{Li}^{+}{ }_{\text {(sol) }}+6 \mathrm{OH}^{-}{ }_{\text {(sol) }}+\mathrm{I}^{-}{ }_{\text {(sol) }} \rightleftarrows 3 \mathrm{H}_{2} \mathrm{O}_{(\text {sol })}+\mathrm{IO}_{3}{ }^{-}{ }_{\text {(sol) }}+6 \mathrm{Li}_{\text {(s) }} . \quad \text { (Reaction 7) }
$$

This reaction is in fact redox mediated via the following two-stage catalytic mechanism in which $\mathrm{I}^{-}$is first oxidized to $\mathrm{I}_{3}{ }^{-}\left(\mathrm{I}^{-} / \mathrm{I}_{3}{ }^{-}\right.$couple, Gibbs free energy: $\Delta_{\mathrm{r}} \mathrm{G}\left(\mathrm{I}^{-} / \mathrm{I}_{3}^{-}\right)$; Reaction 2). Subsequently, $\mathrm{LiOH}$ reacts chemically with $\mathrm{I}_{3}{ }^{-}$to form $\mathrm{IO}^{-}$and $\mathrm{H}_{2} \mathrm{O}$ (Gibbs free energy: $\Delta_{\mathrm{r}} \mathrm{G}\left(\mathrm{OH}^{-} \rightarrow \mathrm{IO}^{-}\right)$):

$$
2 \mathrm{OH}^{-}{ }_{(\mathrm{sol})}+\mathrm{I}_{3}^{-}{ }_{\text {(sol) }} \rightleftarrows \mathrm{I}^{-}{ }_{\text {(sol) }}+\mathrm{H}_{2} \mathrm{O}_{(\mathrm{sol})}+\mathrm{IO}^{-} \text {(sol). }
$$

(Reaction 8)

Finally, $\mathrm{IO}^{-}$disproportionates to form $\mathrm{IO}_{3}^{-}$and $\mathrm{I}^{-}$(Gibbs free energy: $\left.\Delta_{\mathrm{r}} \mathrm{G}\left(\mathrm{IO}^{-} \rightarrow \mathrm{IO}_{3}^{-}\right)\right)$:

$$
3 \mathrm{IO}_{\text {(sol) }}^{-} \rightleftarrows 2 \mathrm{I}^{-} \text {(sol) }+1 \mathrm{IO}_{3}^{-} \text {(sol). }
$$

(Reaction 9)

The Gibbs free energy of $\mathrm{IO}_{3}^{-}$formation $\left(\Delta_{\mathrm{r}} \mathrm{G}\left(\mathrm{OH}^{-} \rightarrow \mathrm{IO}_{3}^{-}\right)\right)$can therefore be calculated from the combination of the Gibbs free energy of these three reactions:

$$
\Delta_{\mathrm{r}} \mathrm{G}\left(\mathrm{OH}^{-} \rightarrow \mathrm{IO}_{3}^{-}\right)=3 \Delta_{\mathrm{r}} \mathrm{G}^{\prime}\left(\mathrm{I}^{-} / \mathrm{I}_{3}^{-}\right)+\Delta_{\mathrm{r}} \mathrm{G}\left(\mathrm{OH}^{-} \rightarrow \mathrm{IO}^{-}\right)+\Delta_{\mathrm{r}} \mathrm{G}\left(\mathrm{IO}^{-} \rightarrow \mathrm{IO}_{3}^{-}\right) \text {. (Equation 7) }
$$

The key step in the $\mathrm{IO}^{-} / \mathrm{IO}_{3}{ }^{-}$route during charge is the reaction of $\mathrm{I}_{3}{ }^{-}$and $\mathrm{OH}^{-}$to form $\mathrm{IO}^{-}$(Reaction 8), as this reversible process is directly in competition with the OER. While the formation of $\mathrm{IO}_{3}{ }^{-}$is thermodynamically downhill with respect to $1 \mathrm{O}^{-}$, the proposed mechanisms require the formation of $\mathrm{IO}^{-}$as an initial step. As previously discussed, the solvation of $\mathrm{I}^{-}$strongly influences the $\mathrm{I}^{-} / \mathrm{I}_{3}{ }^{-}$redox potential, and therefore also $\Delta_{\mathrm{r}} \mathrm{G}\left(\mathrm{OH}^{-} \rightarrow \mathrm{IO}^{-}\right)$. However, the (formally) $\mathrm{I}^{+}$ion in $\mathrm{I}_{3}{ }^{-}$is consumed to create $\mathrm{IO}^{-}$, generating only two $\mathrm{I}^{-}$ions (Reaction 8), as opposed to three $\mathrm{I}^{-}$ions in the OER reaction (Reaction 3 ). The effect of this difference, and whether this is sufficient to create a thermodynamic driving force for $1 \mathrm{O}^{-}$over $\mathrm{O}_{2}$ because of it, can be assessed by examining the overall reaction to form $1 \mathrm{O}^{-}$(Reaction $8+$ Reaction 2).

$$
2 \mathrm{Li}^{+}{ }_{\text {(sol) }}+2 \mathrm{OH}^{-}{ }_{\text {(sol) }}+\mathrm{I}^{-}{ }_{\text {(sol) }} \rightleftarrows 2 \mathrm{Li}_{\text {(s) }}+\mathrm{H}_{2} \mathrm{O}_{(\text {sol })}+\mathrm{IO}^{-}{ }_{(\text {sol) }}, \quad \text { (Reaction 10) }
$$

which competes with the formation of $\mathrm{O}_{2}$ via the OER given in Reaction 1. The competition between these two reactions is described via the following equilibrium:

$$
3 \mathrm{I}^{-} \text {(sol) }+3 / 2 \mathrm{O}_{2} \text { (sol) } \rightleftarrows 3 \mathrm{IO}^{-} \text {(sol). }
$$

(Reaction 11)

The Gibbs free energy for this process can be calculated:

$$
\begin{aligned}
\Delta_{\mathrm{r}} \mathrm{G} & \left(\mathrm{OH}^{-} \rightarrow \mathrm{IO}^{-}\right)-\frac{3}{2} \Delta_{\mathrm{r}} \mathrm{G}\left(\mathrm{OH}^{-} \rightarrow \mathrm{O}_{2}\right)=0.40+3 \Delta_{\mathrm{sol}} \mathrm{G}\left(\mathrm{IO}^{-}\right)-3 \Delta_{\mathrm{sol}} \mathrm{G}\left(\mathrm{I}^{-}\right) \\
& -\frac{3}{2} \mathrm{k} \ln \left(\frac{\mathrm{P}_{\mathrm{O}_{2}}}{\mathrm{P}^{\circ}}\right) .
\end{aligned}
$$

(Equation 8)

This indicates that, under standard conditions (implying $\Delta_{\text {sol }}$ terms are 0 ), the thermodynamic drive for the OER versus $1 \mathrm{O}^{-}$formation is $+0.40 \mathrm{eV}$ (as $3 \Delta_{\mathrm{f}} \mathrm{G}\left(\mathrm{IO}^{-}\right.$) $3 \Delta_{\mathrm{f}} \mathrm{G}\left(\mathrm{I}^{-}\right)=+0.40 \mathrm{eV}$ from Equation 8; see Supplemental Information). ${ }^{41}$ However, the thermodynamic drive is solvent dependent due to differences in solvation energies of $\mathrm{I}^{-}, \mathrm{IO}^{-}$, and $\mathrm{O}_{2}$ (Equation 8). If the value of $\Delta_{\mathrm{sol}} \mathrm{G}\left(\mathrm{O}_{2}\right)$ is assumed to be unchanging in the various electrolytes under consideration, then the thermodynamic balance between the formation of $1 \mathrm{O}^{-}$and $\mathrm{O}_{2}\left(\Delta_{\mathrm{r}} \mathrm{G}\left(\mathrm{OH}^{-} \rightarrow \mathrm{IO}^{-}\right)^{-}\right.$ $\left.\Delta_{\mathrm{r}} \mathrm{G}\left(\mathrm{OH}^{-} \rightarrow \mathrm{O}_{2}\right)\right)$ hinges entirely upon the difference in the Gibbs free energy of solvation of $\mathrm{I}^{-}$and $\mathrm{IO}^{-}$in different electrolytes $\left(\Delta_{\text {sol }} \mathrm{G}\left(\mathrm{IO}^{-}\right)-\Delta_{\text {sol }} \mathrm{G}\left(\mathrm{I}^{-}\right)\right.$). 
To obtain an understanding of the magnitude of the solvation energy terms, density functional theory (DFT) calculations with implicit solvation were performed (see Supplemental Information). The calculated difference in the Gibbs free energy of solvation of $\mathrm{I}^{-}$and $\mathrm{IO}^{-}\left(3 \Delta_{\mathrm{sol}} \mathrm{G}\left(\mathrm{IO}^{-}\right)-3 \Delta_{\mathrm{sol}} \mathrm{G}\left(\mathrm{I}^{-}\right)\right)$is $+0.22 \mathrm{eV}$ in $\mathrm{G} 4$ and $+0.15 \mathrm{eV}$ in pure Pyr ${ }_{14}$ TFSI, making $\Delta_{\mathrm{r}} \mathrm{G}\left(\mathrm{OH}^{-} \rightarrow \mathrm{IO}^{-}\right)-\frac{3}{2} \Delta_{\mathrm{r}} \mathrm{G}\left(\mathrm{OH}^{-} \rightarrow \mathrm{O}_{2}\right)+0.63 \mathrm{eV}$ and +0.55 $\mathrm{eV}$ in $\mathrm{G} 4$ and pure $\mathrm{Pyr}_{14} \mathrm{TFSI}$, respectively; i.e., the formation of $\mathrm{IO}^{-}$is thermodynamically unfavorable in comparison to the OER regardless of the presence or absence of IL.

A similar thermodynamic analysis of the formation of $\mathrm{IO}_{3}{ }^{-}$can be performed (see Supplemental Information):

$$
\begin{aligned}
\Delta_{\mathrm{r}} \mathrm{G}\left(\mathrm{OH}^{-} \rightarrow \mathrm{IO}_{3}^{-}\right)-\frac{3}{2} \Delta_{\mathrm{r}} \mathrm{G}\left(\mathrm{OH}^{-} \rightarrow \mathrm{O}_{2}\right)=-0.79+\Delta_{\mathrm{sol}} \mathrm{G}\left(\mathrm{IO}_{3}^{-}\right)-\Delta_{\mathrm{sol}} \mathrm{G}\left(\mathrm{I}^{-}\right) \\
-\frac{3}{2} \mathrm{kT} \ln \left(\frac{\mathrm{P}_{\mathrm{O}_{2}}}{\mathrm{P}^{\circ}}\right) .
\end{aligned}
$$

(Equation 9)

The formation of $\mathrm{IO}_{3}{ }^{-}$is more thermodynamically favorable than the OER under standard conditions $(-0.79 \mathrm{eV}),{ }^{41}$ and the thermodynamic balance between the formation of $\mathrm{IO}_{3}^{-}$and $\mathrm{O}_{2}$ in different electrolytes again depends on $\left(\Delta_{\mathrm{sol}} \mathrm{G}\left(\mathrm{IO}_{3}^{-}\right)-\right.$ $\Delta_{\text {sol }} \mathrm{G}\left(\mathrm{I}^{-}\right)$). DFT calculations similarly show that the solvation of $\mathrm{IO}_{3}{ }^{-}$in $\mathrm{G} 4$ and $\mathrm{Pyr}_{14}$ TFSI is less favorable than that in water by amounts very similar to those found for $\mathrm{IO}^{-}$and $\mathrm{I}^{-}\left(\Delta_{\mathrm{sol}} \mathrm{G}\left(\mathrm{IO}_{3}^{-}\right)=+0.44\right.$ and $+0.28 \mathrm{eV}$, respectively). This results in the difference in driving force for the formation of $\mathrm{IO}_{3}{ }^{-}$over $\mathrm{O}_{2}$ (Equation 9) being reduced to $-0.627 \mathrm{eV}$ and $-0.557 \mathrm{eV}$ in $\mathrm{G} 4$ and pure $\mathrm{Pyr}_{14} \mathrm{TFSI}$, respectively; i.e., $\mathrm{IO}_{3}{ }^{-}$formation is always favored over the OER in all solvents.

Figure $6 \mathrm{H}$ shows free energy diagrams comparing the thermodynamic drive to form $\mathrm{O}_{2}$ (Equation 5) versus $\mathrm{IO}^{-}$(Equation 8) and $\mathrm{IO}_{3}{ }^{-}$(Equation 9) in electrolytes with and without IL, and in standard conditions. The value of $\mathrm{E}\left(\mathrm{I}^{-} / \mathrm{I}_{3}{ }^{-}\right)$used for the calculations is the one measured for the electrolytes containing $700 \mathrm{mM} \mathrm{LiTFSI}, 50 \mathrm{mM} \mathrm{Lil}$, and 5,000 ppm $\mathrm{H}_{2} \mathrm{O}$ in $\mathrm{G} 4$ with $0 \mathrm{mM}$ and $900 \mathrm{mM} \mathrm{Pyr}{ }_{14} \mathrm{TFSI}\left(\mathrm{E}\left(\mathrm{I}^{-} / \mathrm{I}_{3}{ }^{-}\right)=3.07 \mathrm{~V}\right.$ and $3.24 \mathrm{~V}$, respectively; Figure $5 \mathrm{~A}$ ), while the solvation energy terms were calculated for implicit solvents (in pure G4, $\mathrm{Pyr}_{14} \mathrm{TFSI}$, and water, respectively). The overall thermodynamic analysis indicates that the introduction of $\mathrm{Pyr}_{14} \mathrm{TFSI}$ (Figure $6 \mathrm{H}$ ) to $\mathrm{G} 4$ has two effects: (1) oxidation of $\mathrm{OH}^{-}$by $\mathrm{I}_{3}{ }^{-}$becomes thermodynamically favorable $\left(\Delta_{\mathrm{r}} \mathrm{G}\left(\mathrm{OH}^{-} \rightarrow \mathrm{O}_{2}\right)<0\right)$; (2) $\mathrm{IO}^{-}$formation is never favorable versus the OER, while $\mathrm{IO}_{3}{ }^{-}$is always more thermodynamically favorable. This suggests that the kinetics associated with $\mathrm{IO}_{3}{ }^{-}$formation must also play a role in the observed switch from $1 \mathrm{O}^{-} / \mathrm{IO}_{3}{ }^{-}$formation to OER during charge. Given that the formation of $\mathrm{IO}_{3}{ }^{-}$is the thermodynamic product, and that it requires 3 equivalents of $1 \mathrm{O}^{-}$(Reaction 9), the rate at which this intermediate is formed is of paramount importance. Our results indicate that in water-containing glyme electrolytes, while the conversion to $\mathrm{IO}^{-}$is still thermodynamically unfavorable, it occurs because there is no alternative competing OER reaction; its formation is likely driven by the driving force for $\mathrm{IO}_{3}{ }^{-}$ formation. The introduction of $\mathrm{Pyr}_{14}$ TFSI changes this equilibrium as the OER is now favorable. While $\mathrm{IO}_{3}{ }^{-}$remains the thermodynamic product, the kinetics of its formation involving the reaction of three $\mathrm{IO}^{-}$molecules are unfavorable, which we suggest is key here. The kinetics of iodine redox reactions have been an intensely debated subject on its own for decades, with important ramifications to many fields, ${ }^{44}$ which lies well outside of the scope of this article. It is, however, well understood that kinetically, iodine redox reactions are heavily dependent on the media. For instance, the iodine disproportionation reaction in aqueous media is greatly 
reduced (by up to two orders of magnitude) at high $\mathrm{pHs}$, at which the reaction becomes first order with respect to $\left[1 \mathrm{O}^{-}\right]{ }^{44,45}$

Our MD and ${ }^{1} \mathrm{H}-\mathrm{NMR}$ results confirm that the introduction of the (soft Lewis base) $\mathrm{Pyr}_{14}{ }^{+}$cation to the electrolyte has a strong impact on the coordination of the (soft Lewis acid) $\mathrm{I}^{-}$, replacing $\mathrm{H}_{2} \mathrm{O}, \mathrm{Li}^{+}$, and $\mathrm{G} 4$ to some extent in the environment of $\mathrm{I}^{-}$(Figure 6E), in agreement with previous studies. ${ }^{18,20}$ This suggests that the fast kinetics, of the $1 \mathrm{O}^{-}$formation in water-containing electrolytes, are disturbed by the introduction of $\mathrm{Pyr}_{14}$ TFSI due to efficient donor-acceptor interactions. Furthermore, as the MSD plot (Figure 6F) shows, there is a synergistic interaction between water and the $\mathrm{Pyr}_{14}{ }^{+}$cation on the mobility of $\mathrm{I}^{-}$, which could also play a kinetic role during the charge process.

\section{Conclusions}

Lil-mediated cells in the presence of water and the ionic liquid Pyr ${ }_{14}$ TFSI produce reversible $4 \mathrm{e}^{-} / \mathrm{O}_{2}$ ORR and OER at 2.6 $\mathrm{V}$ and 3.2-3.5 V, respectively, during capacity-limiting galvanostatic cycling as monitored in operando OEMS experiments. A combination of ex situ characterization methods confirm that these reactions occur through the formation/decomposition of $\mathrm{LiOH}$. OEMS experiments with $\mathrm{Li}_{2} \mathrm{O}_{2}$ preloaded electrodes show that the electrolyte mixture is also capable of efficiently decomposing $\mathrm{Li}_{2} \mathrm{O}_{2}$ through a $2 \mathrm{e}^{-} / \mathrm{O}_{2}$ during OER. The presence of $\mathrm{Pyr}_{14}$ TFSI increases the $\mathrm{I}^{-} / \mathrm{I}_{3}{ }^{-}$redox potential, shifting the mechanism of the LiOH OER from the irreversible production of $\mathrm{IO}^{-} / \mathrm{IO}_{3}{ }^{-}$to the evolution of $\mathrm{O}_{2}$. This shift in redox potential can be explained by a change in the solvation conditions of $\mathrm{I}^{-}$in the presence of both water and the IL. Our NMR and MD results indicate that the combination of an IL and water in aprotic electrolytes is an effective strategy for tailoring the electrolyte properties and reaction mechanisms in redox-mediated $\mathrm{Li}^{-} \mathrm{O}_{2}$ batteries. This study reopens the possibility of using $\mathrm{LiOH}$ as a viable, and water-resistant, discharge product in Li-air batteries. Further studies will be needed to understand all the intricate mechanistic details of this chemistry, as well as to improve the overall performance of the cell, especially with regard to rate and long-term reversibility.

\section{EXPERIMENTAL PROCEDURES}

\section{Resource Availability}

Lead Contact

Further information and requests for resources and reagents should be directed to and will be fulfilled by the Lead Contact, Clare P. Grey (cpg27@cam.ac.uk).

Materials Availability

This study did not generate new unique reagents.

Data and Code Availability

The solvation parameters used for implicit solvation DFT calculations are presented in the Supplemental Information.

\section{Materials Preparation}

Carbon electrodes were prepared by kneading a slurry made from 75 wt\% carbon black (Ensaco P150, Imerys) and 25\% PTFE binder (Aldrich, 60\% water solution) in ethanol until a homogeneous film was obtained. Free-standing discs were cut from this film, annealed at $120^{\circ} \mathrm{C}$ in vacuo for $12 \mathrm{~h}$, and transferred to the glovebox without exposure to air. The areal loading of the carbon electrode is $\sim 1-2 \mathrm{mg} / \mathrm{cm}^{2}$. Tetraethylene glycol dimethyl ether (G4, Aldrich, 99\%) was refluxed with sodium metal under Ar for 3 days prior to fractional distillation in vacuo. The final water 
content was measured by Karl Fischer titration (Metrohm) at $<10$ ppm and then stored over $4 \AA$ molecular sieves. Lithium bis(trifluoromethyl)sulfonylimide (LiTFSI, $3 \mathrm{M}$ ) and Lil (Aldrich, $99.9 \%$ ) were dried in vacuo at $160^{\circ} \mathrm{C}$ and $200^{\circ} \mathrm{C}$, respectively for $12 \mathrm{~h}$ before being used to prepare the electrolyte. 1-butyl-1-methyl-pyrrolidinium-bis-(trifluoromethanesulfonyl)-imide ( $\mathrm{Pyr}_{14} \mathrm{TFSI}$, Solvionic 99.9\%; $\mathrm{H}_{2} \mathrm{O} \leq$ $0.002 \%$ ) was used as purchased. All materials were stored and handled in an Ar glovebox with $<0.1 \mathrm{ppm} \mathrm{O}_{2}$ and $<0.1 \mathrm{ppm}_{2} \mathrm{O}$.

\section{Electrochemical Methods}

All $\mathrm{Li}_{2} \mathrm{O}_{2}$ cells were assembled inside an Ar-filled glovebox on bored-through stainless steel Swagelok unions by staking a Li disc (PI-KEM, 99.99\%), 1 piece of pressed borosilicate glass fiber separator (Whatman) wetted with 300 mM LiTFSI / G4 (anolyte), a disk of lithium-ion-conducting glass ceramic (LICGC; Ohara), 1 piece of pressed borosilicate glass fiber separator wetted with the active catholyte $(90 \mu \mathrm{L}$ in $1 / 2$ " and $210 \mu \mathrm{L}$ in 1 " cells, respectively), and Ensaco P150 cathode. Stainless steel mesh (Advent) was used as a current collector. Electrochemical tests were performed on either a Biologic SP-300 or an Ivium Vertex potentiostat/galvanostat. Due to the significant overpotential induced by the use of a LICGC disk, the resistance of the cell was measured by impedance spectroscopy. Ohm's Law was then applied to obtain the Ohmic overpotential (Figure S20), which was then subtracted in the load curves. Galvanostatic cycling was limited to a current of $50 \mu \mathrm{A} / \mathrm{cm}^{2}$ due to kinetic limitations of the very viscous electrolyte (Figures S9-S11, S18, and S19). A newly designed OEMS system was developed for this work, and it is described in detail in the Supplemental Information (Figure S1A). The cell design consists in a Swagelok-type cell with inlet and outlet tubes welded to the top plunger and capped with self-sealing quick-connects (Beswick Engineering) to isolate the cell from the atmosphere between assembly in the glovebox and connection to the OEMS system. Galvanostatic discharge and charge were carried out under $20 \% \mathrm{O}_{2}$ and $0 \% \mathrm{O}_{2}$ in Ar, respectively. A newly designed pressure-monitoring cell assembly was also developed for this work and is described in detail in the Supplemental Information (Figure S1B). A pressure transducer was connected to a Swagelok-type cell and sealed in the glovebox. The cell assembly was then pumped down and subsequently filled up with pure $\mathrm{O}_{2}$. The total internal volume of the setup was measured independently for each test using a reference volume, and the measured change in pressure was then converted to number of moles of gas consumed using the ideal gas law.

\section{Characterization Methods}

Characterization of electrodes after electrochemical tests was performed by first disassembling the cell inside the glovebox, rinsing the cathode twice in $\mathrm{G} 1$, then drying them in vacuo at room temperature. Powder X-ray diffraction measurements were performed with the electrode placed in an air-tight sample holder in a Panalytical Empyrean diffractometer, in reflection mode with $\mathrm{Cu} \mathrm{K \alpha 1}$ radiation $(I=1.5406 \AA$ ). Ultraviolet spectra were acquired on samples in an air-tight quartz cuvette in a PerkinElmer (LAMBDA TM 25/35) spectrometer. G4 was used for dilutions, and pristine electrolyte was used as reference. Scanning electron microscopy was obtained in a Tescan MIRA3 microscope ( $5 \mathrm{keV} ; 7 \mathrm{pA}$ ) with samples transported from the glovebox sealed in a Kammrath \& Weiss transfer module. Solution ${ }^{1} \mathrm{H}-\mathrm{NMR}$ spectra were acquired using an 11.7 T Bruker Avance III HD spectrometer with a single $30^{\circ}(10.5$ $\mu \mathrm{s})$ flip angle pulse sequence - and with a recycle delay of $1 \mathrm{~s}$. DMSO-d 6 was used as solvent. Titration experiments were performed following the method previously reported by McCloskey et al. ${ }^{46}$ Cathodes were extracted from cells inside the glovebox and placed in a sealed vial unwashed. $2 \mathrm{~mL}$ of ultrapure water (Millipore) was 


\section{$\infty$ CellPress}

injected into the vial using a syringe, and then titration of the base was done with a standardized $10 \mathrm{mM} \mathrm{HCl}$ solution, using phenolphthalein as end-point indicator while vigorously stirring. The $\mathrm{LiOH}$ content is calculated based on this acid-base titration. Subsequently, $1 \mathrm{~mL}$ of $\mathrm{KI}(2 \mathrm{wt} \%), 1 \mathrm{~mL}$ of $\mathrm{H}_{2} \mathrm{SO}_{4}(3.5 \mathrm{M})$, and $50 \mathrm{~mL}$ of a molybdenum-based catalyst solution were added. The $\mathrm{I}_{2}$ generated from the reaction of $\mathrm{Li}_{2} \mathrm{O}_{2}$, alongside the $\mathrm{I}_{3}{ }^{-}$present in the unwashed electrodes, was then quickly titrated using $0.01 \mathrm{~N} \mathrm{NaS}_{2} \mathrm{O}_{3}$ solution using a starch indicator, in order to establish the presence or absence of $\mathrm{Li}_{2} \mathrm{O}_{2}$ in the discharge product (Figure S4). Post mortem measurement of water in electrolyte was measured in cells using Super P coated gas diffusion layer electrodes. The separator in the cathode side was wetted with $0.25 \mathrm{~mL}$ of electrolyte (containing $900 \mathrm{mM}$ of IL and 5,000 ppm of water). The cells were then filled with $\mathrm{O}_{2}$ (after 2 pumping/filling cycles) and investigated after resting, discharging, and charging to $2 \mathrm{mAh}$. Subsequently, the gas in the cells was evacuated by pumping for 30 min before introducing the cells into the glovebox for disassembly. The separator and electrode were then removed and stored in a vial in which $0.5 \mathrm{~mL}$ of $\mathrm{G} 4$ was used to wash the electrolyte. $0.3 \mathrm{~mL}$ of washed electrolyte was then collected and added to $34.4 \mathrm{mg}$ LiTFSI to bring its concentration up to $700 \mathrm{mM}$ (LiTFSI was added since its addition results in a shift of the water peak to higher ppm and into a range that does not overlap with the G4 peaks; see Figure S8), stirred for 2 mins, and left to rest for $24 \mathrm{~h} .{ }^{1} \mathrm{H}-\mathrm{NMR}$ of this solution was then collected, and the spectra was normalized with respect to the peak corresponding to the $\mathrm{CH}_{2}$ groups of the IL.

\section{Density Functional Theory Calculations}

To obtain an understanding of the magnitude of the $\Delta_{\text {sol }} \mathrm{G}()$ terms, DFT calculations were performed. In each case, the B3LYP-D3/def2-TZVP level of theory was used. The SMD solvation model ${ }^{47}$ was used for implicit solvation calculations. The builtin parameters for water were used, while for G4 and $\mathrm{Pyr}_{14} \mathrm{TFSI}$, parameters were derived for the calculations (see Supplemental Information).

\section{Molecular Dynamics Simulations}

The simulation boxes were set up, using Packmol, ${ }^{48}$ to be congruent with the experimental concentrations (700 mM LiTFSI, $50 \mathrm{mM}$ Lil in G4, with 5,000 ppm of $\mathrm{H}_{2} \mathrm{O}$ as starting point). Furthermore, water concentration was varied $(0,2,500$, and 10,000 ppm of $\mathrm{H}_{2} \mathrm{O}$ ) as well as the presence/absence of the IL. The role of the concentration of the IL was also explored by varying the number of $\mathrm{Pyr}_{14} \mathrm{TFSI}$ molecules to be 0 , 0.5 , and 1.5 times the experimental concentration $(0 \mathrm{mM}, 450 \mathrm{mM}$, and $1,350 \mathrm{mM}$ ). The full list of values is presented in the Supplemental Information (Table S2). The time step in each simulation was $2 \mathrm{fs}$ as the $\mathrm{C}-\mathrm{H}$ bonds were fixed utilizing LINCS. The forcefield used was OPLS-AA, with additional parameters for $\mathrm{Pyr}_{14}{ }_{14} \mathrm{TFSI}$ from CL\&P. ${ }^{49}$ The SPC water model was used. Scaled charges (to 0.8 ) were also used to speed up the simulation due to the inclusion of an IL in the system. The equilibration procedure was as follows: an initial starting run of $0.2 \mathrm{~ns}$ NVT (Nose-Hoover thermostat set to $298 \mathrm{~K}$ and $1 \mathrm{ps}$ ) followed by two NPT runs, both $4 \mathrm{~ns}$ long (the first one used the Berendsen barostat, set to $1 \mathrm{~atm}$ and $5 \mathrm{ps}$, and the second used the Parrinello-Rahman barostat). The two-step NPT procedure was used due a simulation instability when the Parrinello-Rahman barostat was used directly. The production runs were 10 ns NVT runs, storing output every 2,000 steps.

In each case, short-range cutoffs for non-bonded interactions were set to $1.2 \mathrm{~nm}$. Gromacs versions 2018.2 and 2018.3 were used. ${ }^{50}$ Analysis of the MD trajectories were done using the Gromacs toolchain, e.g., gmx rdf and gmx msd. The coordination number plots were done using the center of mass of each molecule. 


\section{SUPPLEMENTAL INFORMATION}

Supplemental Information can be found online at https://doi.org/10.1016/j.joule. 2020.09.021.

\section{ACKNOWLEDGMENTS}

This research was enabled by funding support from Innovate UK (132220) and the EPSRC (EP/M009521/1 DJR00640). The authors wish to acknowledge experimental contributions to this work by $\mathrm{C}$. Brackstone for help with titration and UV spectroscopy, V. Kunz with water quantification, Dr. Y. Jin with ${ }^{17} \mathrm{O}-$ ssNMR characterization, and S. Engelke with cyclic voltammograms. T.L. acknowledges support from the Schlumberger Fellowship and Darwin College and Thousand Talent Recruitment Programme. E.J. acknowledges support from the Swedish Research Council in the form of an International Postdoc fellowship. Via our membership to the UK's HEC Materials Chemistry Consortium, which is funded by EPSRC (EP/L000202, EP/ R029431), this work used the ARCHER UK National Supercomputing Service (http://www.archer.ac.uk).

\section{AUTHOR CONTRIBUTIONS}

I.T. contributed to project planning, data acquisition, analysis, and article writing; T.L. contributed to project planning; E.P. contributed to project planning and preliminary experiments; J.H.J.E. and G.K. contributed to data acquisition and analysis; E.J. contributed to theoretical data and analysis; C.P.G. contributed to project planning, supervision, and article writing. All authors contributed to the discussion of the results presented and editing.

\section{DECLARATION OF INTERESTS}

C.P.G. and T.L. have a patent pending associated with lithium-air technology.

Received: July 7, 2020

Revised: July 20, 2020

Accepted: September 30, 2020

Published: October 9, 2020

\section{REFERENCES}

1. Bose Styczynski, A., and Hughes, L. (2018). Public policy strategies for next-generation vehicle technologies: An overview of leading markets. Environ. Innov. Soc. Transit. 31, 262-272.

2. Meckling, J., and Nahm, J. (2019). The politics of technology bans: Industrial policy competition and green goals for the auto industry. Energy Policy 126, 470-479.

3. Grey, C.P., and Tarascon, J.M. (2016). Sustainability and in situ monitoring in battery development. Nat. Mater. 16, 45-56.

4. Aurbach, D., McCloskey, B.D., Nazar, L.F., and Bruce, P.G. (2016). Advances in understanding mechanisms underpinning lithium-air batteries. Nat. Energy 1, 16128 .

5. Girishkumar, G., McCloskey, B., Luntz, A.C. Swanson, S., and Wilcke, W. (2010). Lithium-Air Battery: Promise and Challenges. J. Phys. Chem. Lett. 1, 2193-2203.

6. Kwabi, D.G., Ortiz-Vitoriano, N., Freunberger, S.A., Chen, Y., Imanishi, N., Bruce, P.G., and
Shao-Horn, Y. (2014). Materials challenges in rechargeable lithium-air batteries. MRS Bull. $39,443-452$.

7. Liu, T., Vivek, J.P., Zhao, E.W., Lei, J., GarciaAraez, N., and Grey, C.P. (2020). Current Challenges and Routes Forward for Nonaqueous Lithium-Air Batteries. Chem. Rev. $14,6558-6625$.

8. Kwak, W.-J., Rosy, Sharon, D., Xia, C., Kim, H., Johnson, L.R., Bruce, P.G., Nazar, L.F., Sun, Y.-K., Frimer, A.A., et al. (2020). Lithium-Oxygen Batteries and Related Systems: Potential, Status, and Future. Chem. Rev. 14, 6626-6683.

9. Mahne, N., Schafzahl, B., Leypold, C., Leypold, M., Grumm, S., Leitgeb, A., Strohmeier, G.A., Wilkening, M., Fontaine, O., Kramer, D., et al. (2017). Singlet oxygen generation as a major cause for parasitic reactions during cycling of aprotic lithium-oxygen batteries. Nat. Energy 2, 17036.

10. Xia, C., Kwok, C.Y., and Nazar, L.F. (2018). A high-energy-density lithium-oxygen battery based on a reversible four-electron conversion to lithium oxide. Science 361. 777-781.

11. Liu, T., Kim, G. Jónsson, E., Castillo-Martínez, E., Temprano, L. Shao, Y Carretero-González J., Kerber, R.N., and Grey, C.P. (2018). Understanding $\mathrm{LiOH}$ Formation in a $\mathrm{Li}_{-} \mathrm{O}_{2}$ Battery with Lil and $\mathrm{H}_{2} \mathrm{O}$ Additives. ACS Catal. 9, 66-77.

12. Liu, T., Leskes, M., Yu, W., Moore, A.J., Zhou, L., Bayley, P.M., Kim, G., and Grey, C.P. (2015) Cycling $\mathrm{Li}_{-} \mathrm{O}_{2}$ batteries via $\mathrm{LiOH}$ formation and decomposition. Science 350, 530-533.

13. Liu, T., Liu, Z., Kim, G., Frith, J.T., Garcia-Araez, N., and Grey, C. (2017). Understanding $\mathrm{LiOH}$ Chemistry in a Ruthenium-Catalyzed $\mathrm{Li}_{-} \mathrm{O}_{2}$ Battery. Angew. Chem. 129, 16273-16278.

14. Burke, C.M., Black, R., Kochetkov, I.R., Giordani, V., Addison, D., Nazar, L.F., and McCloskey, B.D. (2016). Implications of 4 eOxygen Reduction via lodide Redox Mediation in Li-O $\mathrm{O}_{2}$ Batteries. ACS Energy Lett. 1, 747-756. 
15. Qiao, Y., Wu, S., Sun, Y., Guo, S., Yi, J., He, P. and Zhou, H. (2017). Unraveling the Complex Role of lodide Additives in $\mathrm{Li}-\mathrm{O}_{2}$ Batteries. ACS Energy Lett. 2, 1869-1878.

16. Shen, Y., Zhang, W., Chou, S.-L., and Dou, S.-X. (2015). Comment on "Cycling $\mathrm{Li}_{-} \mathrm{O}_{2}$ batteries via LiOH formation and decomposition". Science 352, 667.

17. Viswanathan, V., Pande, V., Abraham, K.M., Luntz, A.C., McCloskey, B.D., and Addison, D. (2016). Comment on "Cycling $\mathrm{Li}_{-} \mathrm{O}_{2}$ batteries via LiOH formation and decomposition". Science 352, 667.

18. Bentley, C.L., Bond, A.M., Hollenkamp, A.F., Mahon, P.J., and Zhang, J. (2015)

Voltammetric Determination of the lodide/ lodine Formal Potential and Triiodide Stability Constant in Conventional and Ionic Liquid Media. J. Phys. Chem. C 119, 22392-22403.

19. Leverick, G., Tulodziecki, M., Tatara, R., Bardé, F., and Shao-Horn, Y. (2019). SolventDependent Oxidizing Power of Lil Redox Couples for $\mathrm{Li}_{-} \mathrm{O}_{2}$ Batteries. Joule 3, $1106-$ 1126.

20. Nakanishi, A., Thomas, M.L., Kwon, H.-M. Kobayashi, Y., Tatara, R., Ueno, K., et al. (2018) Electrolyte Composition in $\mathrm{Li} / \mathrm{O}_{2}$ Batteries with Lil Redox Mediators: Solvation Effects on Redox Potentials and Implications for Redox Shuttling. J. Phys. Chem. C 122, 1522-1534.

21. Wu, S., Tang, J., Li, F., Liu, X., Yamauchi, Y., Ishida, M., and Zhou, H. (2016). A Synergistic System for Lithium-Oxygen Batteries in Humid Atmosphere Integrating a Composite Cathode and a Hydrophobic Ionic Liquid-Based Electrolyte. Adv. Funct. Mater. 26, 3291-3298.

22. Allen, C.J., Hwang, J., Kautz, R., Mukerjee, S., Plichta, E.J., Hendrickson, M.A., and Abraham, K.M. (2012). Oxygen Reduction Reactions in Ionic Liquids and the Formulation of a General ORR Mechanism for Li-Air Batteries. J. Phys. Chem. C 116, 20755-20764.

23. Elia, G.A., Hassoun, J., Kwak, W.J., Sun, Y.K., Scrosati, B., Mueller, F., Bresser, D., Passerini, S., Oberhumer, P., Tsiouvaras, N., and Reiter, J. (2014). An advanced lithium-air battery exploiting an ionic liquid-based electrolyte. Nano Lett. 14, 6572-6577.

24. Piana, M., Wandt, J., Meini, S., Buchberger, I., Tsiouvaras, N., and Gasteiger, H.A. (2014). Stability of a Pyrrolidinium-Based Ionic Liquid in Li-O $\mathrm{O}_{2}$ Cells. J. Electrochem. Soc. 161, A1992A2001.

25. Shimizu, K., Freitas, A.A., Atkin, R., Warr, G.G., FitzGerald, P.A., Doi, H., Saito, S., Ueno, K., Umebayashi, Y., Watanabe, M., and Canongia Lopes, J.N. (2015). Structural and aggregate analyses of (Li salt + glyme) mixtures: the complex nature of solvate ionic liquids. Phys. Chem. Chem. Phys. 17, 22321-22335.
26. Elia, G.A., Bernhard, R., and Hassoun, J. (2015). A lithium-ion oxygen battery using a polyethylene glyme electrolyte mixed with an ionic liquid. RSC Adv. 5, 21360-21365.

27. Amanchukwu, C.V., Chang, H.-H., Gauthier, M., Feng, S., Batcho, T.P., and Hammond, P.T. (2016). One-Electron Mechanism in a GelPolymer Electrolyte Li- $\mathrm{O}_{2}$ Battery. Chem. Mater. 28, 7167-7177.

28. Mozhzhukhina, N., Tesio, A.Y., De Leo, L.P.M. and Calvo, E.J. (2017). In Situ Infrared Spectroscopy Study of PYR ${ }_{14}$ TFSI Ionic Liquid Stability for Li-O $\mathrm{O}_{2}$ Battery. J. Electrochem. Soc 164, A518-A523.

29. Monaco, S., Soavi, F., and Mastragostino, M. (2013). Role of Oxygen Mass Transport in Rechargeable Li/O 2 Batteries Operating with Ionic Liquids. J. Phys. Chem. Lett. 4, 1379-1382.

30. Liu, T., Frith, J.T., Kim, G., Kerber, R.N., Dubouis, N., Shao, Y., Liu, Z., Magusin, P.C.M.M., Casford, M.T.L., Garcia-Araez, N., and Grey, C.P. (2018). The Effect of Water on Quinone Redox Mediators in Nonaqueous Li$\mathrm{O}_{2}$ Batteries. J. Am. Chem. Soc. 140, 14281437.

31. Meini, S., Solchenbach, S., Piana, M., and Gasteiger, H.A. (2014). The Role of Electrolyte Solvent Stability and Electrolyte Impurities in the Electrooxidation of $\mathrm{Li}_{2} \mathrm{O}_{2}$ in $\mathrm{Li}-\mathrm{O}_{2}$ Batteries. J. Electrochem. Soc. 161, A1306-A1314.

32. $M u, X$., Jiang, J., Deng, H., Qiao, Y., Zheng, M. Zhang, $X$., et al. (2019). $\mathrm{H}_{2} \mathrm{O}$ self-trapping air cathode of $\mathrm{Li}-\mathrm{O}_{2}$ battery enabling low charge potential operating in dry system. Nano Energy 64. 103945.

33. Qiao, Y., Wu, S., Yi, J., Sun, Y., Guo, S., Yang, S., et al. (2017). From $\mathrm{O}_{2}{ }^{-}$to $\mathrm{HO}_{2}^{-}$: Reducing ByProducts and Overpotential in Li- $\mathrm{O}_{2}$ Batteries by Water Addition. Angew. Chem. Int. Ed. 56, 4960-4964.

34. Tulodziecki, M. Leverick, G.M., Amanchukwu, C.V., Katayama, Y., Kwabi, D.G., Barde, F. Hammond, P.T., and Shao-Horn, Y. (2017). The role of iodide in the formation of lithium hydroxide in lithium-oxygen batteries. Energy Environ. Sci. 10, 1828-1842.

35. Haskins, J.B., Yildirim, H., Bauschlicher, C.W., and Lawson, J.W. (2017). Decomposition of Ionic Liquids at Lithium Interfaces. 2. Gas Phase Computations. J. Phys. Chem. C 121, 2823528248.

36. Yildirim, H., Haskins, J.B., Bauschlicher, C.W., and Lawson, J.W. (2017). Decomposition of Ionic Liquids at Lithium Interfaces. 1. Ab Initio Molecular Dynamics Simulations. J. Phys. Chem. C 121, 28214-28234.

37. Mohzhukhina, N., Tesio, A.Y.,Pozo, M.d., and Calvo, E.J. (2017). Communication-Lithium Ion Concentration Effect in $\mathrm{PYR}_{14}$ TFSI Ionic Liquid for $\mathrm{Li}_{-} \mathrm{O}_{2}$ Battery Cathodes. J. Electrochem. Soc. 164, H5277-H5279.
38. Gallant, B.M., Kwabi, D.G., Mitchell, R.R., Zhou, J., Thompson, C.V., and Shao-Horn, Y. (2013). Influence of $\mathrm{Li}_{2} \mathrm{O}_{2}$ morphology on oxygen reduction and evolution kinetics in $\mathrm{Li}-\mathrm{O}_{2}$ batteries. Energy Environ. Sci. 6, 2518-2528.

39. Lu, Y.-C., and Shao-Horn, Y. (2013). Probing the Reaction Kinetics of the Charge Reactions of Nonaqueous Li-O2 Batteries. J. Phys. Chem. Lett. 4,93-99.

40. McCloskey, B.D., Bethune, D.S., Shelby, R.M. Girishkumar, G., and Luntz, A.C. (2011) Solvents' Critical Role in Nonaqueous LithiumOxygen Battery Electrochemistry. J. Phys. Chem. Lett. 2,1161-1166.

41. J. Rumble, ed. (2019). CRC Handbook of Chemistry and Physics (CRC Press).

42. Pearson, R.G. (1963). Hard and Soft Acids and Bases. J. Am. Chem. Soc. 85, 3533-3539.

43. Liu, T., Kim, G., Carretero-González, J., Castillo-Martínez, E., and Grey, C.P. (2016). Response to Comment on "Cycling $\mathrm{Li}_{-} \mathrm{O}_{2}$ batteries via $\mathrm{LiOH}$ formation and decomposition". Science 352, 667.

44. Truesdale, V.W. Luther, G.W., and Greenwood, J.E. (2003). The kinetics of iodine disproportionation: a system of parallel second-order reactions sustained by a multispecies pre-equilibrium. Phys. Chem. Chem. Phys. 5, 3428-3435.

45. Truesdale VW Canosa-Mas, C and Luther lii, G.W. (1994). Kinetics of disproportionation of hypoiodous acid. J. Chem. Soc., Faraday Trans. 90, 3639-3643.

46. McCloskey, B.D., Valery, A., Luntz, A.C. Gowda, S.R., Wallraff, G.M., Garcia, J.M., et al. (2013). Combining Accurate $\mathrm{O}_{2}$ and $\mathrm{Li}_{2} \mathrm{O}_{2}$ Assays to Separate Discharge and Charge Stability Limitations in Nonaqueous $\mathrm{Li}^{-\mathrm{O}_{2}}$ Batteries. J. Phys. Chem. Lett. 4, 2989-2993.

47. Marenich, A.V., Cramer, C.J., and Truhlar, D.G. (2009). Universal solvation model based on solute electron density and on a continuum model of the solvent defined by the bulk dielectric constant and atomic surface tensions. J. Phys. Chem. B 113, 6378-6396.

48. Martínez, L., Andrade, R., Birgin, E.G., and Martínez, J.M. (2009). PACKMOL: a package for building initial configurations for molecular dynamics simulations. J. Comput. Chem. 30, 2157-2164.

49. Canongia Lopes, J.N., and Padua, A.A.H (2004). Molecular Force Field for Ionic Liquids Composed of Triflate or Bistriflylimide Anions. J. Phys. Chem. B 108, 16893-16898.

50. Abraham, M.J., Murtola, T., Schulz, R., Szilard, P., Smith, J.C., Hess, B., and Lindahl, E. (2015). GROMACS: High performance molecular simulations through multi-level parallelism from laptops to supercomputers. SoftwareX 1 2,19-25. 